\title{
RESILIENCE TO DROUGHTS IN MAMMALS: A CONCEPTUAL FRAMEWORK FOR ESTIMATING VULNERABILITY OF A SINGLE SPECIES
}

\author{
TASMin L. RYMER \\ College of Marine Ev Environmental Sciences and Centre for Tropical \\ Environmental E Sustainability Sciences, James Cook University \\ Cairns, Queensland 4870 Australia \\ School of Animal, Plant E Environmental Sciences, University of the Witwatersrand \\ Johannesburg 2050 South Africa \\ E-MAIL: TASMIN.RYMER@JCU.EDU.AU \\ Neville Pillay \\ School of Animal, Plant Eं Environmental Sciences, University of the Witwatersrand \\ Johannesburg 2050 South Africa \\ E-MAIL: NEVILLE.PILLAY@WITS.AC.ZA

\section{Carsten Schradin} \\ School of Animal, Plant E Environmental Sciences, University of the Witwatersrand \\ Johannesburg 2050 South Africa \\ Institut Pluridisciplinaire Hubert Curien-Département Ecologie, \\ Physiologie et Ethologie, Université de Strasbourg \\ Strasbourg 67087 France \\ CNRS, UMR7178 \\ Strasbourg 67087 France \\ E-MAIL: CARSTEN.SCHRADIN@IPHC.CNRS.FR
}

KEYWORDS

allostasis, homeostasis, metabolism, osmoregulation, preadaptation, thermoregulation

The Quarterly Review of Biology, June 2016, Vol. 91, No. 2

Copyright $(2016$ by The University of Chicago Press. All rights reserved.

0033-5770/2016/9102-0002\$15.00 
ABSTRACT

The frequency and severity of droughts in certain areas is increasing as a consequence of climate change. The associated environmental challenges, including high temperatures, low food, and water availability, have affected, and will affect, many populations. Our aims are to review the behavioral, physiological, and morphological adaptations of mammals to arid environments, and to aid researchers and nature conservationists about which traits they should study to assess whether or not their study species will be able to cope with droughts. We provide a suite of traits that should be considered when making predictions about species resilience to drought. We define and differentiate between general adaptations, specialized adaptations, and exaptations, and argue that specialized adaptations are of little interest in establishing how nondesert specialists will cope with droughts. Attention should be placed on general adaptations of semidesert species and assess whether these exist as exaptations in nondesert species. We conclude that phenotypic flexibility is the most important general adaptation that may promote species resilience. Thus, to assess whether a species will be able to cope with increasing aridity, it is important to establish the degree of flexibility of traits identified in semidesert species that confer a fitness advantage under drying conditions.

$\mathrm{A}$

\section{INTRODUCTION} loss (Galbraith et al. 2002), fragmentation (Fahrig 2003), and climate change (Etterson and Shaw 2001; Alley et al. 2003), is accelerating at a rate unprecedented in Earth's history (Etterson and Shaw 2001; Alley et al. 2003). In fact, the rate of vertebrate species climatic niche evolution is considerably slower than the current predicted rates of anthropogenic environmental change (Quintero and Wiens 2013). The accelerated rates of human-induced environmental change could thus be driving a sixth mass extinction event, requiring conservation efforts to be focused on reducing the rate of extinctions (Pimm 2009; Black et al. 2011; Harley 2011). However, we are currently unable to predict which species will be threatened by extinction under increased environmental change and which species will survive (Moritz and Agudo 2013).

Many studies have assessed the probability and potential of species to adapt to rapid environmental change via evolutionary adaptation (e.g., evolutionary rescue; Gonzalez et al. 2013; Box 1). However, evolutionary adaptation is generally a slow process, occurring over generations (Hoffmann and Sgrò 2011), and may occur too slowly for species to respond to rapid environmental and climate change. Under such circumstances, species may become extinct, change their distribution range, or show an active response to change through adaptive (Breed et al. 2011; Box 1) or exaptive (Ghalambor et al. 2007; Box 1) phenotypic plasticity. Interestingly, a number of local declines and extinctions due to environmental change have been associated with changes in species interactions (Cahill et al. 2013; Ockendon et al. 2014). However, an individual's ability to cope with its prevailing environment is also dependent on its behavior, physiology, and morphology. These responses to abiotic factors then likely also influence species interactions, for example, through changes in activity patterns, ultimately further impacting extinction risk.

One of the main consequences of global climate change is an increase in the frequency and intensity of droughts (IPCC 2007; Dai 2011). Regions where droughts have become, and are projected to become, longer and more frequent include the Mediterranean, central Europe, central North America, and southern Africa (IPCC 2007). Although the latest IPCC report (2013) mentions a lower confidence for the increased incidence of droughts since the $1950 \mathrm{~s}$, it is still predicted that droughts are likely to increase in some areas in the future. Droughts are a normal part of climate variation, which means that, independent of global climate change, natural populations have and will continue to face this problem repeatedly. For example, in the last 500 years, 


\begin{tabular}{|c|c|}
\hline \multicolumn{2}{|r|}{$\begin{array}{c}\text { BOX } 1 \\
\text { Definition of terms }\end{array}$} \\
\hline Term & Definition \\
\hline Adaptive phenotypic plasticity & $\begin{array}{l}\text { Alteration of some aspect of the phenotype in re- } \\
\text { sponse to prevailing environmental conditions, which } \\
\text { increases an individual's chance of survival and repro- } \\
\text { duction (maximizes fitness; Charmantier et al. 2008; } \\
\text { Ozgul et al. 2009, 2010; Piersma and van Gils 2010) } \\
\text { and that may facilitate population persistence and } \\
\text { potentially evolutionary adaptation (Hoffmann and } \\
\text { Sgrò 2011). Traits that specifically evolved in response } \\
\text { to historical selection pressures and have current util- } \\
\text { ity in the same context (phenotypic adaptation). }\end{array}$ \\
\hline Aridity index & $\begin{array}{l}I_{m}=\frac{(100 S-60 D)}{P} \text {; where } I_{m}=\text { index of moisture } \\
\text { availability; } S=\text { total moisture surplus }(\mathrm{mm}) \text { from } \\
\text { all months with a water surplus; } D=\text { total of all } \\
\text { monthly deficiencies }(\mathrm{mm}) \text {; and } \mathrm{PE}=\text { annual po- } \\
\text { tential evapotranspiration (mm; Meigs } 1953) \text {. Both } \\
S \text { and } D \text { are represented by the difference between } \\
\text { monthly precipitation and monthly potential evapo- } \\
\text { transpiration (Nash and Engineering Group Work- } \\
\text { ing Party } 2012) \text {. Deserts have an aridity index below } \\
0.2 \text {, semideserts between } 0.2 \text { and } 0.5 \text {. }\end{array}$ \\
\hline Behavioral evader & $\begin{array}{l}\text { Animals able to escape environmental extremes us- } \\
\text { ing primarily behavioral and physiological adapta- } \\
\text { tions (Willmer et al. 2000). }\end{array}$ \\
\hline Developmental plasticity & $\begin{array}{l}\text { Nonreversible phenotypic plasticity occurring during } \\
\text { ontogeny (Piersma and Lindström 1997). }\end{array}$ \\
\hline Drought & $\begin{array}{l}\text { Current precipitation falls significantly below the } \\
\text { long-term mean of a defined area (Dai 2011). Is } \\
\text { defined on a temporal scale and can occur in any } \\
\text { environment. }\end{array}$ \\
\hline Drought-affected areas & $\begin{array}{l}\text { Areas that are neither deserts nor semideserts, but ex- } \\
\text { perience unpredicted droughts, which might occur } \\
\text { more often and become more intense in the future } \\
\text { due to climate change (Li et al. 2009). In the fu- } \\
\text { ture, increasingly more areas might become drought } \\
\text { prone due to climate change. }\end{array}$ \\
\hline Environmental stressor & $\begin{array}{l}\text { Any stimulus that could affect an individual nega- } \\
\text { tively if it cannot respond to it via a specific stress } \\
\text { response, which itself is costly (e.g., Charmandari et } \\
\text { al. 2005). Typically uncontrollable for the individ- } \\
\text { ual, but can be predictable (e.g., seasonal changes } \\
\text { in food) or unpredictable (e.g., a storm; Wingfield } \\
2013 \text { ). }\end{array}$ \\
\hline & continued \\
\hline
\end{tabular}




\section{BOX 1}

Continued

Term Definition

Evolutionary adaptation

Exaptation

Exaptive phenotypic plasticity

Interannual rainfall variability

Phenotypic flexibility

Physiological endurer

Predictable environment

Resilience

Unpredictable environment

Vulnerability
Change in the relative gene frequencies of alleles (and associated phenotypic changes) within a population over multiple generations, with a corresponding increase in species fitness over time (Pianka 2011; Rezende and Diniz-Filho 2012).

Formerly called preexisting adaptations or preadaptations. Traits that evolved in response to historical selection pressures, which have current utility but in a different context (i.e., different environment or selection pressures; Gould and Lewontin 1979).

Alteration of traits in response to prevailing environmental conditions, which specifically evolved in response to historical selection pressures and have current utility in a different context (exaptation), increasing an individual's chance of survival and reproduction (increasing fitness) in novel environments (Ghalambor et al. 2007).

Expressed as a percentage of the mean deviation of precipitation from the average over the average precipitation (Nash and Engineering Group Working Party 2012).

Reversible phenotypic plasticity (Piersma and Lindström 1997).

Animals that tolerate environmental extremes using physiological and morphological adaptations (Willmer et al. 2000).

Resources spatially and/or temporally heterogeneous; selection pressures imposed on populations over multiple generations are seasonal/cyclical (e.g., Negus et al. 1986; Ylönen and Ronkainen 1994); species show evolutionary adaptation and phenotypic plasticity in response to change (Ledón-Rettig et al. 2008; Rymer et al. 2013).

The ability of a species (populations or individuals) to persist following a disturbance or disturbances (Hughes et al. 2007; Tanentzap et al. 2013; Hodgson et al. 2015).

Resources spatially and/or temporally heterogeneous with random, rare, or sporadic environmental changes (Valladares et al. 2002); rapid environment pressure imposed on individuals; and species show phenotypic flexibility in response to change (Piersma and Drent 2003; Rymer et al. 2013).

The predisposition or susceptibility of a species (population or individual) to be negatively affected by a disturbance (Smit et al. 2000; Williams et al. 2008; Oppenheimer et al. 2014). 
megadroughts (extreme drought events persisting for several years) have occurred in North America, China, and West Africa (Dai 2011).

Droughts are characterized by periods of unusually low water availability due to reduced precipitation and/or increased evaporation due to increased temperatures (Dai 2011). Droughts create water shortages, leading to reduced plant primary productivity (McNaughton et al. 1983) and thus an associated food reduction for animals, ultimately leading to an increased risk of individual death and population extinction (Miller et al. 2005; Seager et al. 2007). Animals exposed to such environmental conditions may respond through changes in behavior, physiology, and/or morphology that facilitate survival and/or reproduction. If individual differences in survival/reproductive probabilities are due to genetic differences, genetic selection within the population will result in evolutionary adaptation (Rezende and Diniz-Filho 2012). Under drought conditions, reproduction is often terminated or forfeited, and dry seasons are typically the nonbreeding season (Pinter 1994; Schradin and Pillay 2005; Sperry and Weatherhead 2008). Droughts represent periods of low resource availability that individuals must survive in order to reach a season when reproduction again becomes possible. For this reason, our focus rests with survival and not on reproductive success.

Individuals can cope with droughts using a variety of morphological, physiological, and behavioral traits, and to predict the extent to which species are resilient to droughts requires some measure of these traits. Here, we review these traits to provide researchers and nature conservationists with a guide to which phenotypic traits should be studied in order to assess whether or not a species of interest may be able to cope with droughts. We describe three different ways species can cope with droughts, namely through evolutionary adaptation (future change), adaptive phenotypic plasticity (current change), and exaptations (including exaptive phenotypic plasticity, current change). We focus specifically on adaptive phenotypic plasticity (as per Ghalambor et al. 2007) here, although we recognize that phenotypic plasticity is not necessarily always adaptive, as the environment can also induce changes that decrease fitness, for example, due to constraints or morphological changes indicating significant costs. Another example is evolutionary traps, whereby a fitness increasing ("good") choice changes into a fitness decreasing ("poor") one as previously reliable environmental cues become unreliable, leading to an evolutionary mismatch and thereby trapping the individual into continuing use of the poorer option (Robertson et al. 2013), which could be particularly common in predictable environments (Box 1). Within this context, we argue that whether a trait is specialized and fixed or flexible is important for determining the resilience (the ability to persist following a disturbance or disturbances; Hughes et al. 2007; Tanentzap et al. 2013; Hodgson et al. 2015) or vulnerability (predisposition or susceptibility to be negatively affected by a disturbance; Smit et al. 2000; Williams et al. 2008; Oppenheimer et al. 2014) of a species (or population) to droughts (Box 1). Species with fixed adaptations to droughts are generally well adapted to arid environments, although in species with flexible adaptations and exaptations, the degree of flexibility determines resilience and will likely facilitate adaptive evolution in novel environments (Ghalambor et al. 2007). Resilience to droughts requires individuals to be able to cope with three environmental stressors: water shortage, food shortage, and fluctuating (often very high) temperatures. We define the term "environmental stressor" as any stimulus that could affect an individual negatively if it cannot respond to it via a specific stress response, which itself is costly to some extent. A stress response can be an increase in energy mobilization (i.e., increased blood glucocorticoid levels to mobilize energy; Charmandari et al. 2005), but also comprise other physiological responses (for example, decrease of blood glucocorticoid levels, if the stressor is reduced energy availability and the individual has to reduce energy mobilization). 
Stressors are typically uncontrollable for the individual. For example, the individual cannot control rainfall during a given period. Stressors can occur predictably (e.g., seasonal changes in food) or unpredictably (e.g., a storm; Wingfield 2013).

We then highlight some approaches to categorize behavioral, physiological, and morphological traits of mammals for existence in deserts and semideserts and introduce our own categorization system, the adaptive triquetra, which categorizes traits facilitating coping with aridity instead of categorizing the species themselves. The adaptive triquetra system considers the primary driving stressor, the body system mounting the adaptive response (behavior, physiology, and/or morphology), and the extent to which this trait is flexible. We suggest that the selection pressures operating in deserts (defined below) drive the evolution of specialized, nonplastic adaptations, whereas those in semideserts (defined below) promote phenotypic flexibility. We also stress that traits that could potentially facilitate future coping (which would be classified as exaptations) must not be ignored. We focus our explanation of the adaptive triquetra on mammals, which are one of the best studied taxa for desert adaptations. Although adaptations in other taxa, such as insects and birds, might be quite different, we believe that our general conclusions would apply to them as well. Finally, we conclude that the degree of flexibility of traits that exist as exaptations in nondesert species will determine how well they can cope with droughts, and comparing their degree of flexibility with those of species from semideserts will enable us to predict their resilience.

\section{Evolutionary Adaptation, Adaptive Phenotypic Plasticity, AND Exaptations}

Evolutionary adaptation involves genetic changes over generations (Rezende and Diniz-Filho 2012). Over time, species may show genetic changes, leading to changes in morphology (e.g., peppered moths Biston betularia; Saccheri et al. 2008), physiology (e.g., red abalone Haliotis rufescens; de Wit and Palumbi 2013), and behavior (e.g., bird song; Podos et al. 2004). The degree of adaptive phenotypic plasticity also represents an evolutionary adaptation. These adaptations confer a fitness advantage and evolved in response to particular past selection pressures (Baum and Larson 1991; Coddington 1994). Evolutionary adaptation represents how species responded to previous environmental change, and raises the question of whether, and the degree to which, species can respond to prevailing environmental change via genetic change. Although it is becoming increasingly recognized that evolutionary adaptation can be quite rapid (Hoffmann and Sgrò 2011), the evolutionary response to a changing environment can be constrained by a lack of genetic variation or genetic correlations (i.e., genetic constraints; Chevin 2013), the rate at which individuals within a population reproduce (Lewontin 1970), and the rate and predictability at which the strength and direction of selection changes (due to environmental change) over time (Lande and Shannon 1996; Gomulkiewicz and Houle 2009; Chevin 2013; Michel et al. 2014).

Species might not be adapted to prevailing specific environmental pressures, but may still show some degree of resilience to change due to exaptations, also called preexisting adaptations or preadaptations (e.g., Pekár et al. 2013). In contrast to evolutionary adaptations, exaptations are traits that evolved in response to specific past selection pressures, and provide a fitness advantage in the prevailing environment under different selection pressures, meaning that the past and current environments are different for at least some specific aspects (Gould and Lewontin 1979). In other words, these traits provide a function in their current role, but were not selected for this purpose (Gould and Vrba 1982). For example, Hoffman (2014) proposed that euryhalinity (i.e., salinity tolerance) in the green toad Bufo vir$i d i s$ evolved to facilitate migration across the variable habitats of Eurasia and the North African Mediterranean coastal regions. These toads now occupy arid and semiarid regions, 
suggesting that euryhalinity is an exaptation important for drought resistance (Hoffman 2014). Euryhalinity in these toads did not evolve in response to direct selection pressure from an arid or semienvironment (i.e., evolved in response to past selection pressure), but it does have current utility (i.e., provides a use in the existing context). The usefulness of the term exaptation has frequently been criticized because exemplary traits are often not clearly distinguishable from adaptations (Larson et al. 2013). The distinction between adaptation and exaptation is particularly important to consider when assessing whether an individual could survive in a future environment not experienced previously, as is predicted under accelerated environmental change (Sih et al. 2011). Existing phenotypic plasticity is likely to be of importance in the prevailing environment, even if it has evolved under different selection pressures in a different environment (i.e., exaptive phenotypic plasticity; Box 1). Therefore, a population might be able to respond to increased severity of droughts, not because it previously experienced droughts and is adapted to droughts, but because it experienced different environmental conditions that imposed similar selection pressures (e.g., food shortage). This population could thus possess beneficial exaptations in response to droughts.

Adaptive phenotypic plasticity is an evolved trait, enabling a comparatively rapid response by individuals to cope with environmental change. Phenotypic traits are altered adaptively in response to prevailing environmental conditions, which increases individual fitness (Charmantier et al. 2008; Ozgul et al. 2009, 2010; Piersma and van Gils 2010). Adaptive phenotypic plasticity may determine an individual's survival and reproduction in the short term, which may facilitate population persistence and evolutionary adaptation in the long term (West-Eberhard 1989; Hoffmann and Sgrò 2011). This could be especially important for juveniles and subadults that might be more vulnerable to stressful conditions than adults (e.g., Rivers et al. 2012). Importantly, adaptive phenotypic plasticity itself is the product of evolution (Baldwin 1896). Phenotypic plasticity can be divided into developmental plasticity and phenotypic flexibility (Piersma and van Gils 2010; Box 1). For developmental plasticity (Nettle and Bateson 2015), the environment during early ontogeny determines which one of two or more developmental pathways is adopted, leading to alternative adult phenotypes that cannot change to any of the other phenotypes (Ledón-Rettig et al. 2008). The resulting phenotype is often robust, being able to cope with environmental changes. For developmental plasticity to be adaptive, the population must have experienced particular environments in the past and, as a result, the developmental input to produce particular phenotypes under particular sets of conditions experiences positive selection (Nettle and Bateson 2015). In other words, individuals experience a particular environment during early development that is predictive of the environmental conditions they are likely to experience in later life. In the case of phenotypic flexibility, the trait can change back and forth (i.e., it is reversible), such as changes of the osmoregulatory hormone arginine vasopressin (AVP), whose levels increase when the organism has to save water, but later decrease again. Importantly, individuals may have both developmentally plastic traits and also phenotypically flexible traits.

One specific case of developmental plasticity is epigenetic variation (Piersma and van Gils 2010; Champagne 2013). Epige netic mechanisms can also be influenced by hormones, which can link organizational effects of hormones to differences in behavior (Champagne and Rissman 2011). Importantly, epigenetic inheritance can occur via at least four different pathways, including cellular epigenetic inheritance (information transmitted via the gametes), developmental inheritance (information transmitted via maternal effects), behavioral inheritance (information transmitted via niche construction), and symbiotic inheritance (Jablonka and Lamb 2005, 2007; Piersma and van Gils 2010). Several recent reviews have focused on the links between epigenetics and phenotypic plasticity (e.g., Reik 2007; Champagne and Rissman 2011; Champagne 2013; Bale 2015; Dochtermann et al. 2015). However, 
the majority of studies on phenotypic plasticity provide little or no information on the underlying genetic and epigenetic mechanisms. Therefore, in the context of this review, we consider plasticity in general, rather than in relation to the absolute underlying mechanisms, by determining how variable the trait can be under varying environmental conditions.

Phenotypic plasticity has been hypothesized to be costly because of the need for the development and continued maintenance of neural structures (Dukas 1999), and sensory and/or response pathways involved in facilitating the flexible response (DeWitt et al. 1998; Mery and Burns 2010). However, estimating the actual costs of plasticity is difficult, and these costs might be more easily detected under certain conditions. For example, costs of plasticity are said to be greater in stressful conditions, and if plasticity utilizes resources that become scarce in response to the stress, these costs would be easier to detect (Steiner and Van Buskirk 2008). Van Buskirk and Steiner (2009) argue that the costs of plasticity are actually relatively weak and there might be a compromise or tradeoff between the fitness benefits and costs of greater phenotypic plasticity. One of the main costs of plasticity might be the time needed to mount an appropriate plastic response. Because plasticity seems to have surprisingly low costs, it has been argued recently that relaxed and variable selection intensities are more important constraints for the evolution of plasticity than are its costs (Murren et al. 2015).

Phenotypic plasticity, enabling a coping response to droughts, can either be evolutionary adaptations (adaptive phenotypic plasticity) or exaptations (exaptive phenotypic plasticity). For example, all mammals have the hormone AVP, which is important in osmoregulation, but not all mammals have experienced droughts as a selection pressure modifying the AVP system. Therefore, an increase of AVP plasma levels to reduce water loss during droughts might be higher in desert species, representing an adaptation to previous droughts, but would also occur-although maybe at a lower level-in species from nondesert environments when exposed to droughts, as an exaptation that evolved to save water under different environmental conditions, such as during winter or during periods when food has a lower water content due to seasonal changes. In sum, phenotypic plasticity can have very low flexibility (being fixed) or high flexibility, and represent adaptations or exaptations to droughts.

\section{Three Primary Stressors of Arid Environments}

Identifying the limits of phenotypic plasticity is foundational for assessing the degree to which individuals can respond to rapid environmental change. To evaluate which adaptations and exaptations could promote species persistence to increased periodicity and/or intensity of droughts, we will focus on species that currently inhabit areas characterized by periods of dryness (i.e., semideserts and deserts) with low annual precipitation and high aridity index (Box 1).

Deserts and semideserts are characterized by three principal environmental stressors, namely low water availability, low food availability, and extremes in temperature. The definition of "drought" is a relative one, taken to mean that current precipitation falls significantly below the long-term mean of a defined area (Dai 2011). In this context, drought is defined on a temporal scale and can occur in any environment. In contrast, naturally dry areas, such as deserts, experience permanent water shortage, and semideserts experience seasons with water shortage. An aridity index, used in conjunction with total rainfall, enables us to categorize habitats based on water availability (e.g., deserts versus semideserts; Nash and Engineering Group Working Party 2012). Hyperarid areas, such as the northeastern parts of the Negev Desert in Israel (Boroda et al. 2014), experience more than 12 months without rainfall, have less than $25 \mathrm{~mm}$ rainfall/annum, and an average aridity index below 0.05 , whereas arid areas, such as the Namib Desert in southwestern Africa (Viles and Goudie 2013), receive less than $100 \mathrm{~mm}$ of rainfall per year, which is often very unreliable, and have an aridity index 
below 0.2 (Nash and Engineering Group Working Party 2012). In our review, we group both arid categories into "deserts," as the selection pressures in both habitat types will drive the establishment of specialized adaptations (see below). Semideserts, such as the Hardeveld of the Succulent Karoo in South Africa (Acocks 1988) and the Victoria River district in Australia (Webb et al. 2014), generally receive between 100 and $200 \mathrm{~mm}$ of rainfall per year on average, have a moderate aridity index of between 0.2 and 0.5 , and a 25-50\% interannual rainfall variability (for definition see Box 1; Nash and Engineering Group Working Party 2012). We define "drought-affected areas" as those that are neither deserts nor semideserts, but experience unpredictable droughts, which might occur more often and become more intense in the future due to climate change (Box 1).

Deserts and semideserts are characterized by low food availability. Under these conditions, vegetation is typically sparse and patchily distributed across the landscape (Zhang et al. 2005). Consequently, food availability and quality is spatially and temporally variable and the availability of food resources might be unpredictable. For example, some areas might experience seasonal periods of dryness, which are relatively predictable (predictable environment; Box 1), while other areas might experience unpredictable, extreme climatic events leading to droughts (unpredictable environment; Box 1). Animals inhabiting these environments have to cope both with periods of low water availability and simultaneously low food availability (Willmer et al. 2000). One important consideration is that plants in deserts are also adapted to low water availability (Chaves et al. 2003), whereas plants in areas experiencing increased frequencies of droughts due to climate change may not be adapted to cope with dry conditions over long periods (Vicente-Serrano et al. 2013). As a result, food and water availability in drought-affected areas may have an even greater influence on animal populations than those in naturally dry areas.

Ambient temperature $\left(T_{a}\right)$ is the third factor influencing species in naturally dry and in drought-affected areas. These habitats are often characterized by extreme daily fluctuations in $\mathrm{T}_{\mathrm{a}}$ that can range from very cold at night to very hot during the day, a consequence of reduced absorption of heat by vegetation (Sarma et al. 2001), leading to greater reflection of solar radiation by the ground during the day (i.e., increased albedo; Charney et al. 1977), and rapid loss of heat at night (Sarma et al. 2001). Animals living in naturally dry environments have evolved under selective pressures of fluctuating temperature and tend to show specific behavioral, physiological, and/or morphological adaptations to these environmental extremes. For example, several large desert artiodactyls (Table 1), such as camels Camelus dromedarius (Elkhawad 1992; Ouajd and Kamel 2009) and Arabian oryx Oryx leucoryx (Hetem et al. 2012), utilize the carotid rete, a network of interlacing arterioles in the venous sinus, for selective brain cooling (Hetem et al. 2012). Venous blood cooled through the nasal countercurrent exchange mechanism (Ouajd and Kamel 2009) drains into the venous sinus, cooling the arterial blood moving to the brain (Mitchell et al. 1987).

To identify flexible traits that could confer a fitness advantage under conditions of increasing aridity, it is useful to study species that inhabit deserts or semideserts. Categorizing species living in these dry environments can help us to: identify key adaptations that have arisen in response to aridity; establish a comparative database of traits that can be used to compare with other species for which we lack information; and recognize traits in nondesert-adapted species that could promote responses to increasing aridity and droughts.

\section{Categorizing Species From \\ Deserts AND SEMideserts as ENDURERS OR EVADERS}

Willmer et al. (2000) classified desert animals into two main groups-physiological endurers, such as the Arabian oryx, which are able to tolerate environmental extremes using physiological and morphological adaptations (Table 1) and behavioral evaders, such as Merriam's kangaroo rat 
TABLE 1

Characteristic desert adaptations of physiological endurers and behavioral evaders

\begin{tabular}{|c|c|c|c|}
\hline Behavior & Physiology & Morphology & $\begin{array}{c}\text { Principal examples } \\
\text { and references }\end{array}$ \\
\hline \multicolumn{3}{|c|}{ Mechanisms for coping with water restriction } & Physiological endurers \\
\hline $\begin{array}{l}\text { - Can go for extended } \\
\text { periods without } \\
\text { drinking }{ }^{[11, o],[2 b, e, f]} \text {, shows } \\
\text { water independence }{ }^{[4 c]} \text {, } \\
\text { or may survive on water } \\
\text { gained through food } \\
\text { [2d,e,f,g,h], [3f,k], [4j] } \\
\text { - Reduced food intake }{ }^{[10]}\end{array}$ & 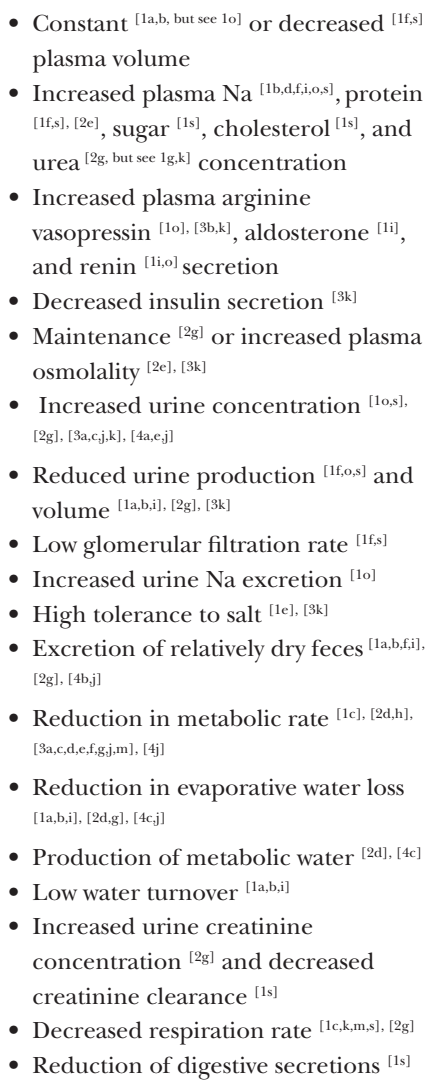 & $\begin{array}{l}\text { - Nasal countercurrent } \\
\text { exchange system }{ }^{[1 \mathrm{j}, \mathrm{s}]}, \\
\text { [4d,j]} \\
\text { - Well-developed nasal } \\
\text { glands }{ }^{[1 \mathrm{~s}]} \\
\text { - Nostrils can close } \\
\text { completely }{ }^{[1 \mathrm{~s}]} \\
\text { - Kidney with long loops } \\
\text { of Henle and well- } \\
\text { developed medulla }{ }^{[1 \mathrm{~s}]} \\
\text { - Increased tubular } \\
\text { reabsorption of the } \\
\text { kidney }{ }^{[1 \mathrm{~s}],[2 \mathrm{~g}]} \\
\text { - Thin erythrocyte with } \\
\text { increased surface area: } \\
\text { volume ratio }{ }^{[1 \mathrm{~s}]}\end{array}$ & 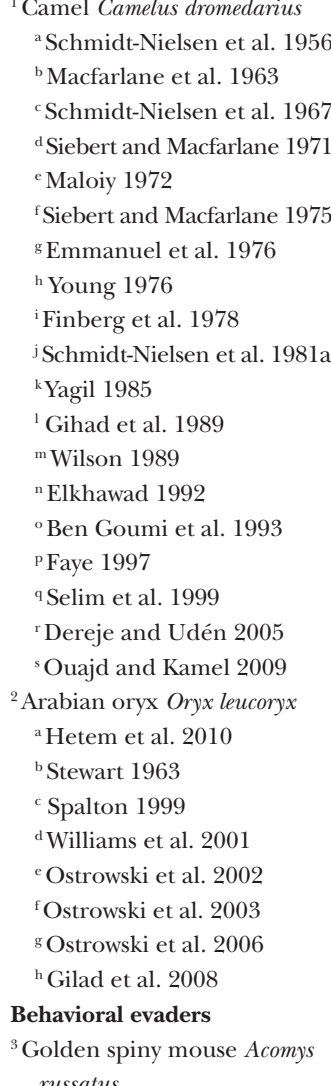 \\
\hline \multicolumn{3}{|c|}{ Mechanisms for coping with food restriction } & ${ }^{a}$ Shkolnik and Borut 1969 \\
\hline 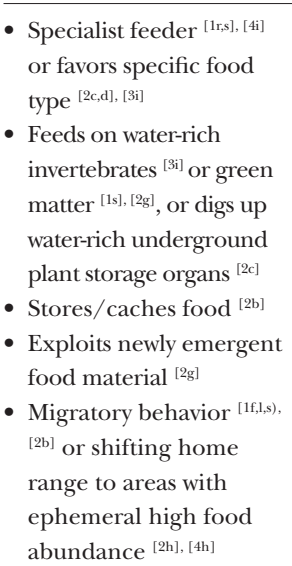 & $\begin{array}{l}\text { - Maintenance }{ }^{[3 f, \mathrm{~m}]} \text { or minimal loss of } \\
\text { body mass }{ }^{[1 \mathrm{a}, \mathrm{f}, \mathrm{s}],[2 \mathrm{~g}]} \text { for physiological } \\
\text { endurers, but tolerance to loss of } \\
\text { body mass }{ }^{[3, \mathrm{k}, \mathrm{k}]} \text { for behavioral evaders } \\
\text { - Mobilization of hepatic lipids }{ }^{[1 \mathrm{~s}]} \text { and } \\
\text { fatty acids }{ }^{[2 \mathrm{~g}]} \text { to fuel metabolism } \\
\text { - Decreased leptin production }{ }^{[2 \mathrm{~g}],[3 \mathrm{~m}]} \\
\text { - Good aptitude for recycling nitrogen } \\
\text { - Enters torpor }{ }^{[3 \mathrm{~g}, \mathrm{~m}]}\end{array}$ & $\begin{array}{l}\text { - Reduction in organ } \\
\text { size/volume }{ }^{[2 \mathrm{~g}]} \\
\text { - Strong digestive } \\
\text { efficiency }{ }^{[1 \mathrm{q}, \mathrm{s}],[2 \mathrm{~g}]} \\
\text { - Storage of fat/lipids } \\
{[1 \mathrm{r}],[3 \mathrm{~m}]}\end{array}$ & $\begin{array}{l}{ }^{\mathrm{b}} \text { Castel and Abraham } 1972 \\
{ }^{\mathrm{c}} \text { Haim and Borut } 1981 \\
{ }^{\mathrm{d}} \text { Rubal et al. } 1992 \\
{ }^{\mathrm{e}} \text { Haim and Izhaki } 1993 \\
{ }^{\mathrm{f}} \text { Kam and Degen } 1993 \\
{ }^{\mathrm{g}} \text { Merkt and Taylor } 1994 \\
{ }^{\mathrm{h}} \text { Haim and Rozenfeld } 1995 \\
{ }^{\mathrm{i}} \text { Mendelssohn and Yom-Tov } \\
\text { 1999 } \\
\text { j Ron and Haim } 2001 \\
{ }^{\mathrm{k}} \text { Shanas and Haim } 2004 \\
{ }^{\mathrm{I}} \text { Ehrhardt et al. } 2005 \\
{ }^{\mathrm{m}} \text { Gutman et al. } 2006\end{array}$ \\
\hline
\end{tabular}


TABLE 1

Continued

\begin{tabular}{|c|c|c|c|}
\hline Behavior & Physiology & Morphology & $\begin{array}{l}\text { Principal examples } \\
\text { and references }\end{array}$ \\
\hline \multicolumn{3}{|c|}{ Mechanisms for coping with extreme temperatures } & ${ }^{4}$ Merriam's kangaroo rat \\
\hline 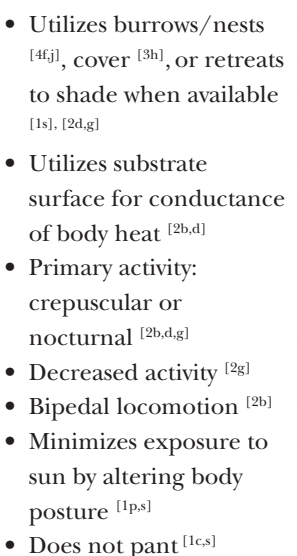 & 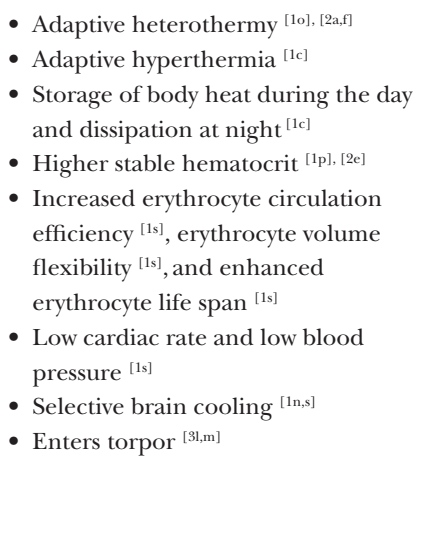 & $\begin{array}{l}\text { - Subdivision of nasal } \\
\text { sinus }{ }^{[1 \mathrm{j}],[4 \mathrm{~d}, \mathrm{~g}]} \\
\text { - Limited subcutaneous } \\
\text { fat deposition }{ }^{[\mathrm{h}, \mathrm{s}]} \\
\text { - Short coarse pelage }{ }^{[2 \mathrm{~b}]} \\
\text { - Light-colored pelage } \\
\text { for reflecting solar } \\
\text { radiation and reducing } \\
\text { heat uptake }{ }^{[2 \mathrm{~b}]} \\
\text { - Maintenance of } \\
\text { nonshivering } \\
\text { thermogenesis }{ }^{[3 \mathrm{se}]} \\
\text { - Dark pigmented } \\
\text { skin }^{[3 \mathrm{hh}]}\end{array}$ & $\begin{array}{l}\text { Dipodomys merriami } \\
\text { a Schmidt-Nielsen et al. } \\
1948 \\
\text { b Schmidt-Nielsen and } \\
\text { Schmidt-Nielsen } 1951 \\
\text { b Schmidt-Nielsen and } \\
\text { Schmidt-Nielsen } 1952 \\
\text { c } 3 \text { Jackson and Schmidt- } \\
\text { Nielsen } 1964 \\
\text { e Carpenter } 1966 \\
{ }^{\mathrm{d}} \text { Soholt } 1974 \\
{ }^{\mathrm{g}} \text { Schmidt-Nielsen et al. } 1970 \\
{ }^{\mathrm{h}} \text { Brown and Munger } 1985 \\
{ }^{\mathrm{i}} \text { Mares } 1993 \\
{ }^{\mathrm{j}} \text { Nagy } 1994\end{array}$ \\
\hline
\end{tabular}

Superscript numbers designate species (endurers: ${ }^{1}$ Camelus dromedarius, ${ }^{2}$ Oryx leucoryx; evaders: ${ }^{3}$ Acomys russatus, ${ }^{4}$ Dipodomys merriami) and letters designate associated references, which appear in Appendix 1.

Dipodomys merriami, which are able to escape environmental extremes behaviorally (Table 1). Later, Ward (2009) recognized that endurers are typically large-bodied animals while evaders are typically smallbodied animals.

The endurer-evader concept is useful for categorizing desert specialists primarily in relation to one characteristic of arid environments, namely extremes in environmental temperature $\left(T_{a}\right)$. However, this concept is a simplistic approach, based on the assumption that it is easier for small animals to find refuge in the shade than it is for large animals, while in fact we know that large animals will use any little shade they can find in their environment to avoid high $\mathrm{T}_{\mathrm{a}}$ (Williams et al. 2001; Ostrowski et al. 2006; Ouajd and Kamel 2009). Although this concept, to a degree, considers the ability of animals to be behaviorally flexible (e.g., seeking shade), it generally assumes that animals have limited flexibility in their behavioral and morphological responses and neglects the important aspect of exaptive phenotypic plasticity, which we consider to be a key mechanism to cope with change, including droughts. As such, the endurer-evader categorization provides an initial framework from which to further identify important traits to be studied in nondesert-adapted species for coping with heat, food, and water restriction as a consequence of droughts.

\section{A Novel Classification: The AdAPtive Triquetra}

Given the simplicity of the endurer-evader concept, we developed a three-tier system, the adaptive triquetra, that categorizes adaptations to aridity instead of categorizing species (Box 2). Having a species categorization is not helpful for generalizing adaptations across species, and importantly overlooks the underlying general adaptive responses to drought. We stress that providing this framework is only the first step. The framework we develop here must be validated in the future by data from a variety 


\section{BOX 2 \\ Using the adaptive triquetra system}

The adaptive triquetra considers a three-step approach that can be used for either: directly assessing resilience in species for which good biological information already exists; and/or for identifying areas where more research may be required. For example, if someone is interested in a particular species, they might have good knowledge of its life history, but little knowledge about its environment, and could therefore focus on establishing which environmental stressor is more important before understanding how the species could respond. Similarly, someone might have good knowledge about the physiology of a species, but little about its behavior. Focus could be placed on how that species responds behaviorally to particular environmental stressors.

Step 1

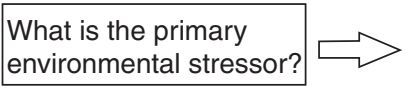

Step 2

What traits correspond to each body system?
Step 3

What is the relative flexibility of each trait?

Step 1: What is the Primary Environmental Stressor? (Water, Food, Temperature) Consider the environment in which the species of interest occurs, and what the primary stressor would be, taking microhabitat use into account (Tables 2a, b, and c). This is important because not all habitats will experience the same intensity of change and some environments will buffer some stressors better than others. For example, temperature extremes might be more critical in subtropical areas experiencing droughts than in temperate or polar climate zones. For a diurnal burrowing rodent, such as Brants's whistling rat Parotomys brantsii (Jackson et al. 2004), extreme temperatures may not represent a problem due to the buffering effects of burrows.

Step 2: What Traits Correspond to Each Body System? (Behavioral, Physiological, Morphological)

This step considers the presence of, and number of traits, corresponding to each system (Tables 2a, b, and c). The greater the number of traits allowing for coping with the stressors, the more likely it is that the species might be able to cope with rapid environmental changes. However, this will also heavily depend on the flexibility of the traits (Step 3).

Step 3: What is the Relative Flexibility of Each Trait? (Fixed, Developmentally Plastic, Flexible)

The ability of a species to persist under increasing likelihood of droughts is dependent on how individuals are able to respond with the traits they possess. An individual has a greater likelihood of responding to unpredictable events if it has greater flexibility (Tables 2a, b, and c). The interaction between two traits can also change the potential for resilience. For example, the interaction between a fixed morphological trait and a flexible behavioral trait is important for African striped mice Rhabdomys pumilio in the Succulent Karoo of South Africa. Striped mice have dark skin (Schradin and Pillay 2005), which facilitates thermoregulation through basking (Schradin et al. 2007), allowing mice to conserve energy in the early morning when temperatures are lower. 
of different species and different research programs to determine its accuracy, and then modified as appropriate. Our comprehensive review of adaptations to droughts of specialist and nonspecialist species provides the foundational information needed for such future research programs on the effects of droughts on individual survival and population and species persistence.

The term "triquetra" is derived from the Latin tri- "three" and quetrus "cornered," emphasizing the three-tiered nature of this classification system, as well as the interconnectedness of its parts. Our adaptive triquetra considers: which stressor is addressed (water restriction, food restriction, or extremes in $\mathrm{T}_{\mathrm{a}}$ ); which body system mounts an appropriate adaptive response (behavior, physiology, or morphology); and the nature of the trait (fixed versus flexible). Although these stressors are often interlinked (e.g., plants are dependent on water and, therefore, food is likely to be restricted if water is restricted), we argue that each stressor should first be examined independently, because some species might have adaptations or exaptations that facilitate better coping with one stressor compared to another. This is especially important for designing effective management strategies to support populations at risk. For example, during a severe drought period (1981-1984) in southern Africa, mortality of herbivores was quite high, but in some areas, such as the northeastern Tuli region of Botswana, mixed grazers-browsers (e.g., impala Aepyceros melampus) were little affected compared to grazers (e.g., blue wildebeest Connochaetes taurinus and zebra Equus burchelli), whereas in other areas, such as the central Kruger National Park in South Africa, the same grazers (blue wildebeest and zebra) were unaffected (Walker et al. 1987). Walker et al. (1987) suggest that mortality in Klaserie Reserve in South Africa (adjacent to the Kruger National Park) was heightened by close spacing of permanent water sources. Heavy grazing occurred around these areas, eliminating reserve stands. Instead, dropping fences and widely spacing water sources would have allowed animals to move between areas, accessing forage and promoting survival. Therefore, supplemental feeding in Klaserie could have been highly beneficial to promote species survival.

\section{WHICH STRESSOR IS ADDRESSED?}

The first step of the adaptive triquetra model is to identify which of the three primary stressors has driven the evolution of the particular adaptation in question (Box 2). First, low water availability leads to the need for improved osmoregulation, resulting in adaptations that reduce water loss or increase waterintake (Table 2a). Second, since food availability is a direct consequence of water restriction, there is a need for improved energy storage mechanisms, resulting in adaptations that minimize energy loss or maximize energy gain (Table 2b). These include both intrinsic adaptations, such as storage of body fat (e.g., Mongolian gerbils Meriones unguiculatus; Zhang and Wang 2007), and extrinsic adaptations, such as food caching (e.g., kangaroo rats Dipodomys spp.; Randall 1993). Third, high $\mathrm{T}_{\mathrm{a}}$ leads to the need for improved thermoregulatory ability, resulting in adaptations that decrease the risk of overheating or increase the ability to tolerate heat (Table 2c).

These three stressors are not fully independent of each other. For example, in mammals, the need for improved thermoregulation is directly related to the need to save water because the ability to reduce water loss in mammals is constrained by the need for evaporative cooling to reduce overheating (Taylor 1970). Furthermore, water can be obtained from food directly (e.g., consumption of succulents by viscacha rats Octomys mimax; Bozinovic and Contreras 1990) and/or indirectly (e.g., use of metabolic water by the desert pocket mouse Chaetodipus penicillatus; Grubbs 1980). However, most animals cannot obtain sufficient water from their food to survive without access to freestanding water or condensed water. For species that are dependent on freestanding water, the primary stressor will be water availability, whereas for water-independent species, the primary stressor will be food availability. 
TABLE 2A

The adaptive triquetra system for the environmental stressor water restriction

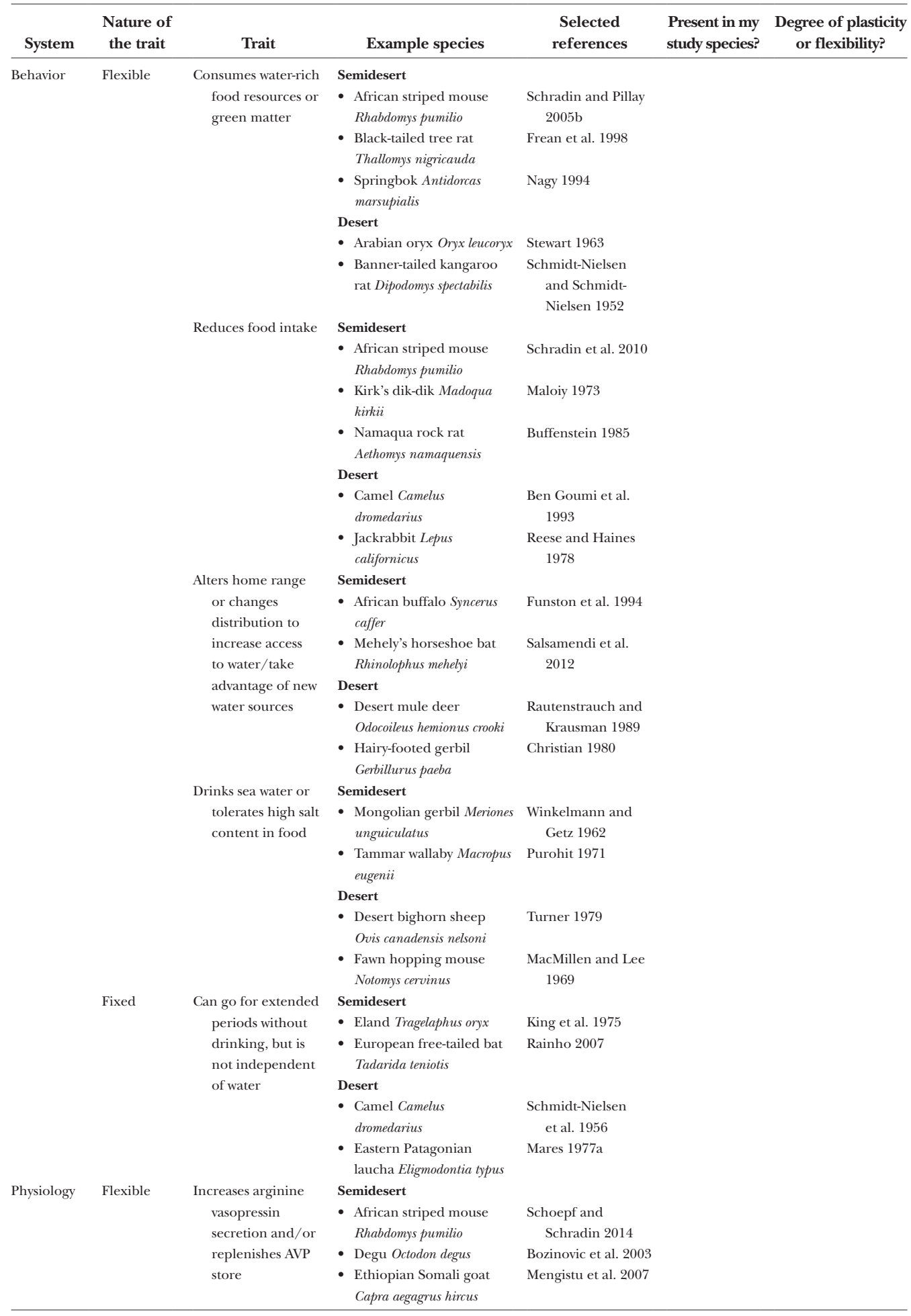


TABLE 2A

Continued

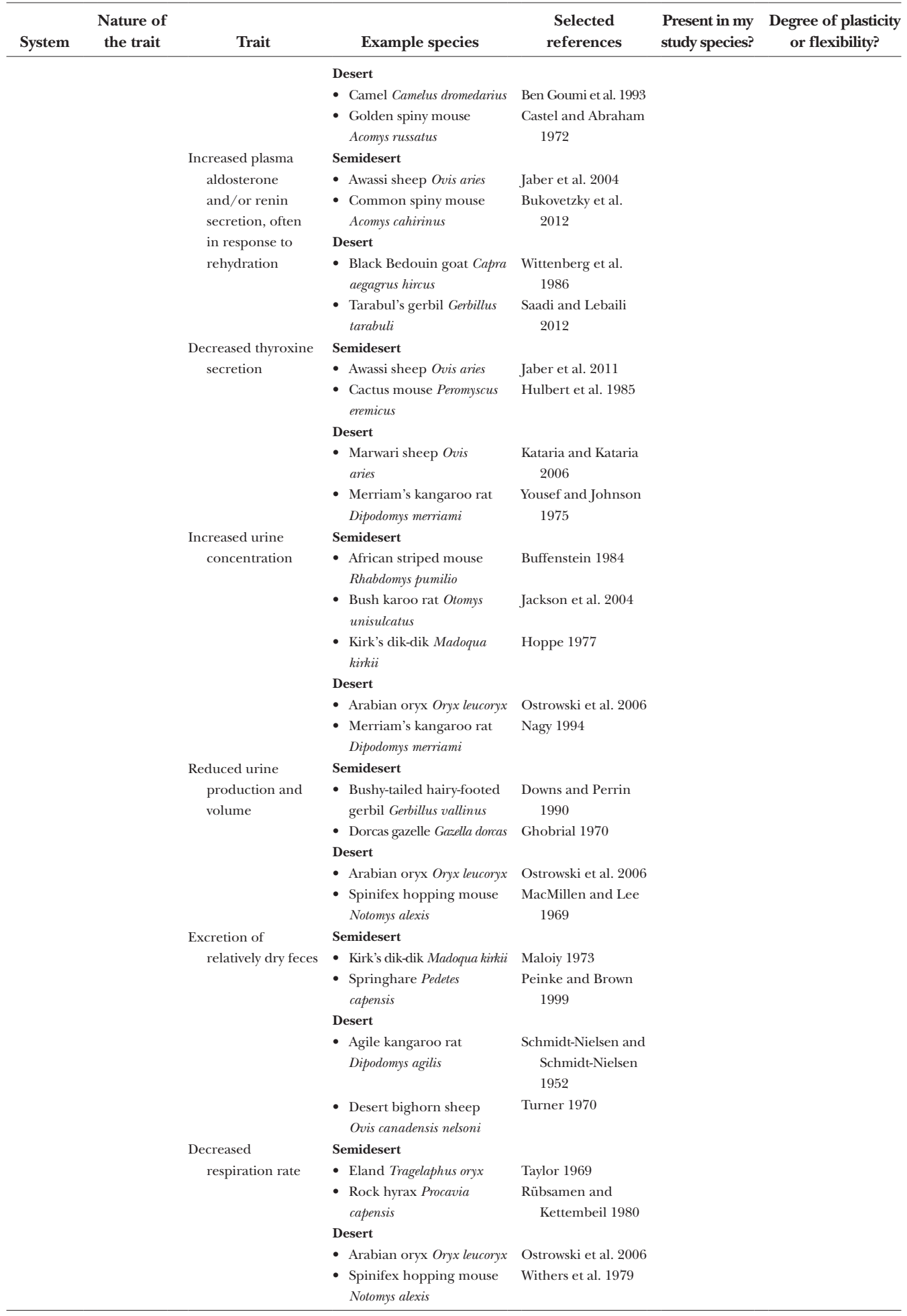


TABLE 2A

Continued

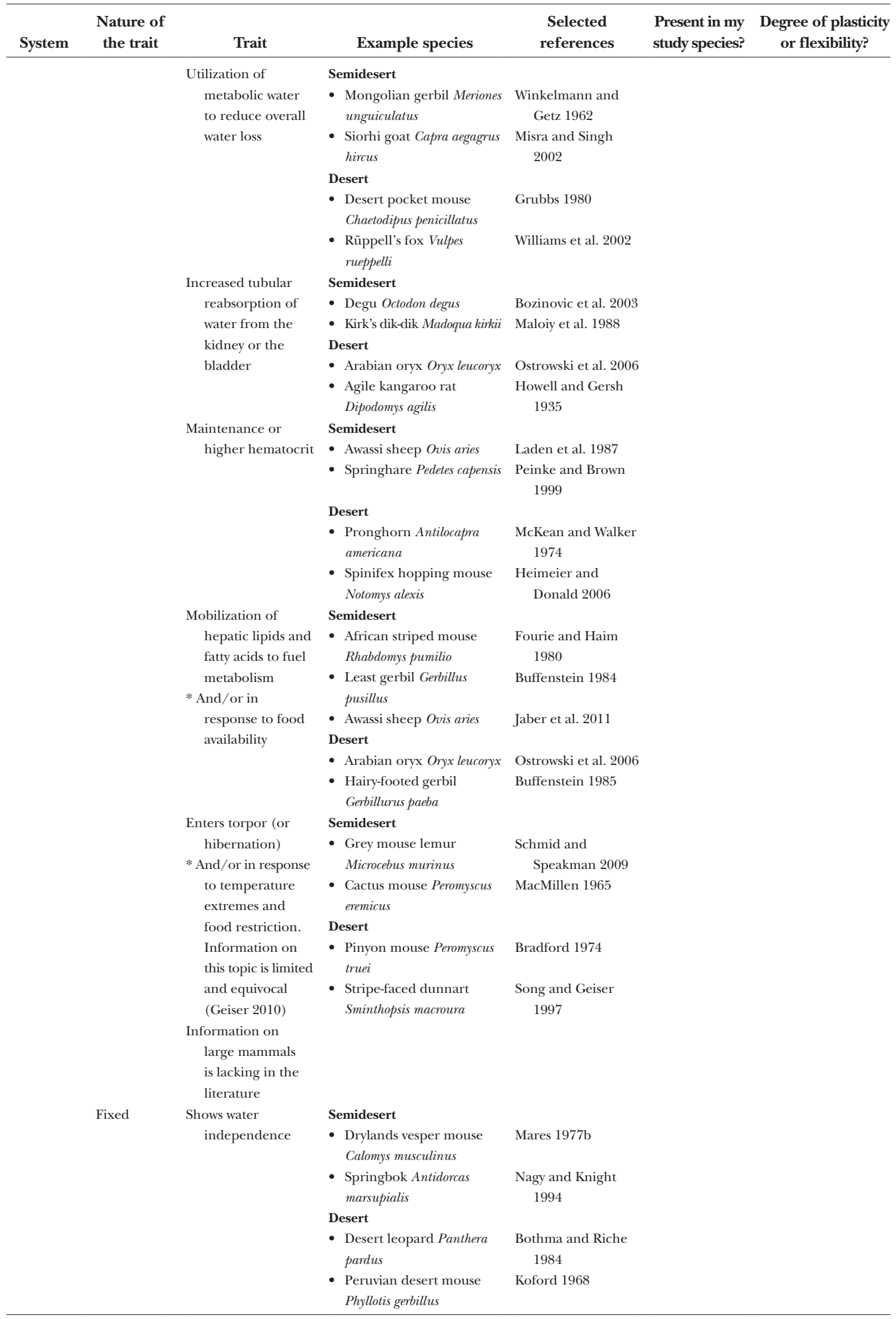


TABLE 2A

Continued

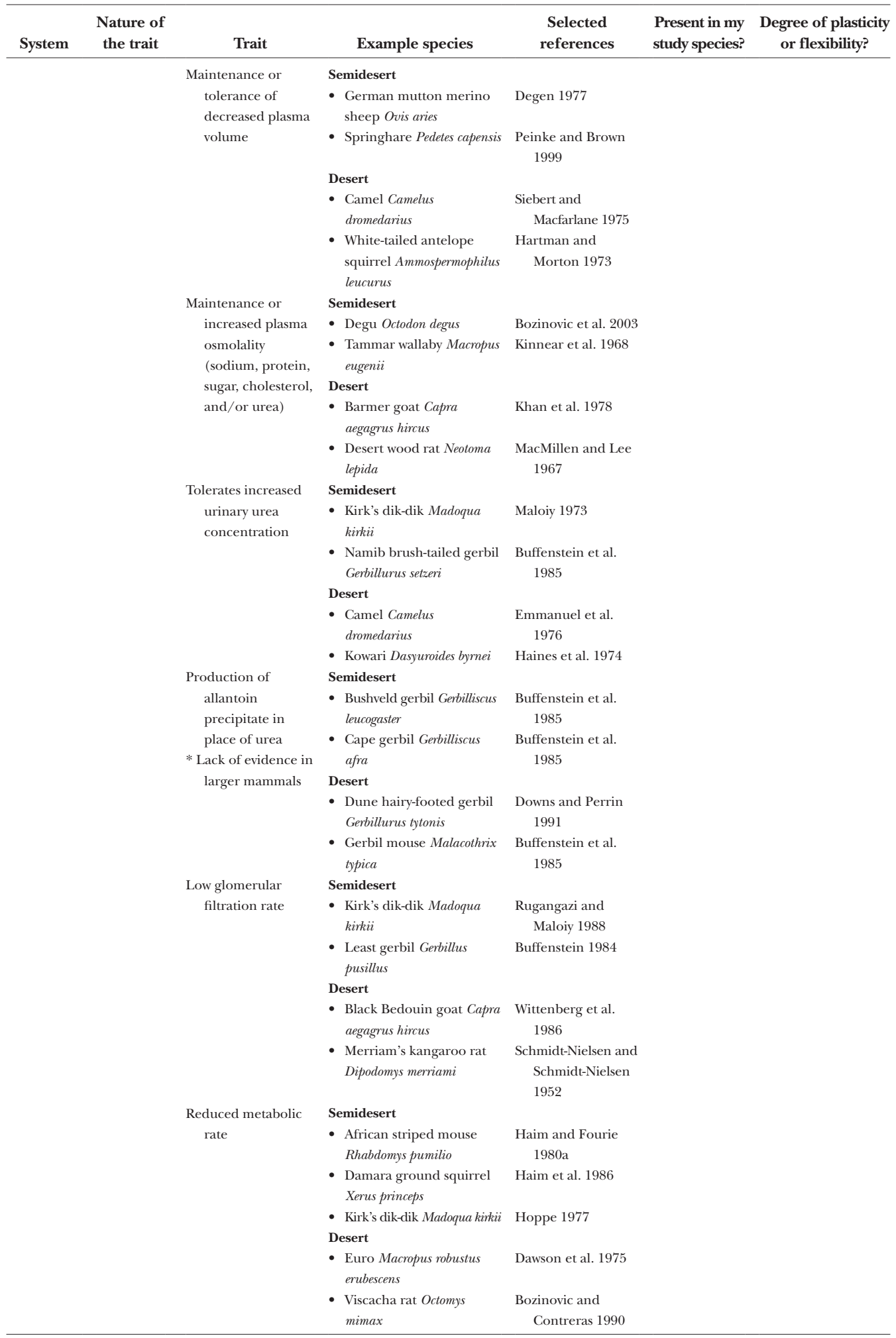


TABLE 2A

Continued

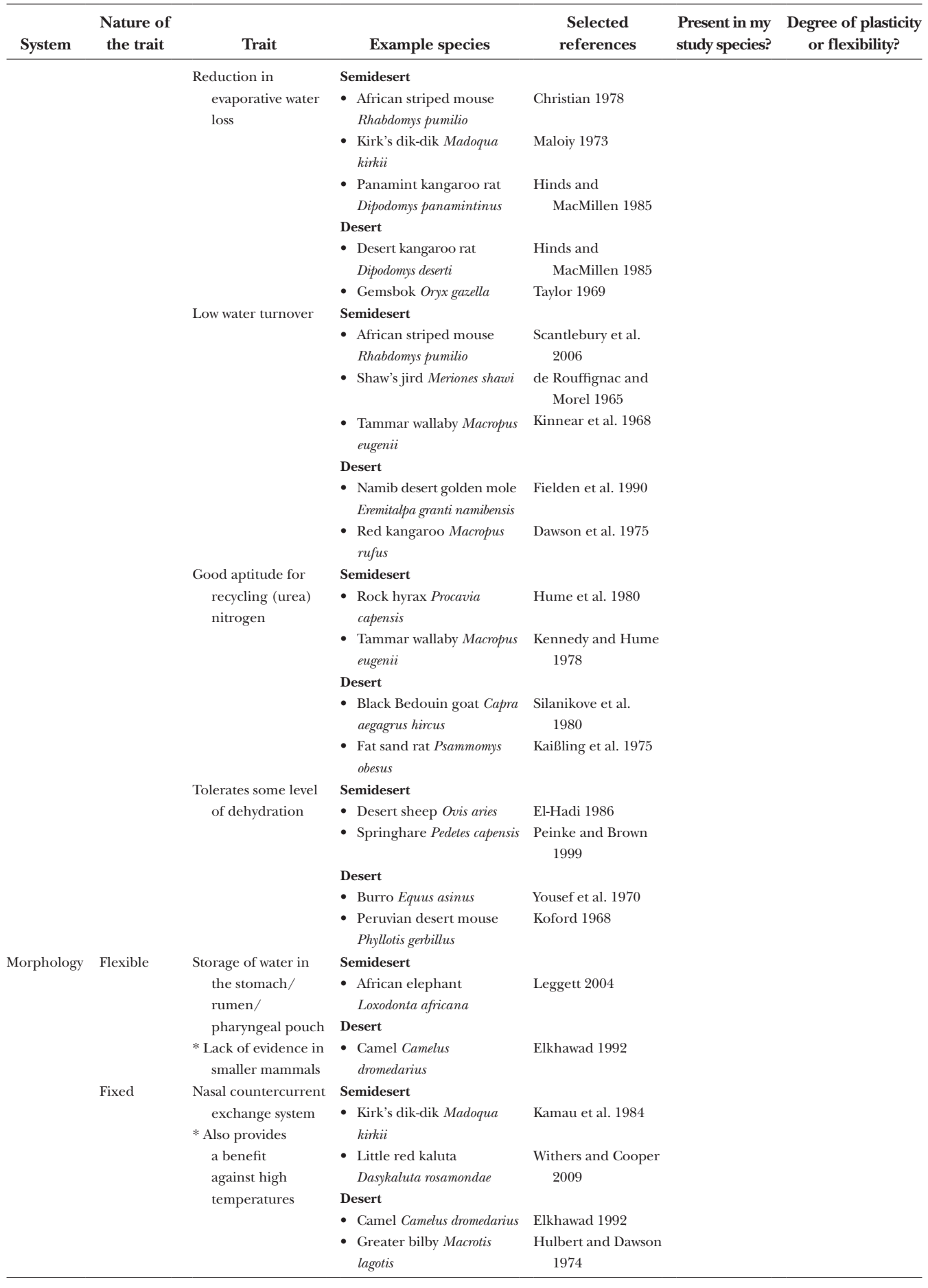


TABLE 2A

Continued

\begin{tabular}{|c|c|c|c|c|c|c|}
\hline System & $\begin{array}{l}\text { Nature of } \\
\text { the trait }\end{array}$ & Trait & Example species & $\begin{array}{l}\text { Selected } \\
\text { references }\end{array}$ & $\begin{array}{l}\text { Present in my } \\
\text { study species? }\end{array}$ & $\begin{array}{l}\text { Degree of plasticity } \\
\text { or flexibility? }\end{array}$ \\
\hline & & \multirow{9}{*}{$\begin{array}{l}\text { Kidney with } \\
\text { well-developed } \\
\text { medulla and long } \\
\text { loops of Henle }\end{array}$} & Semidesert & & & \\
\hline & & & - Salt flat mouse Salinomys & Diaz and Ojeda & & \\
\hline & & & delicatus & 1999 & & \\
\hline & & & $\begin{array}{l}\text { - Tammar wallaby Macropus } \\
\text { eugenii }\end{array}$ & Kinnear et al. 1968 & & \\
\hline & & & Desert & & & \\
\hline & & & - Camel Camelus & Ouajd and Kamel & & \\
\hline & & & dromedarius & 2009 & & \\
\hline & & & - Darwin's leaf-eared & Vermeulen and $\mathrm{Nel}$ & & \\
\hline & & & $\begin{array}{l}\text { mouse Phyllotis darwini } \\
\text { darwini }\end{array}$ & 1988 & & \\
\hline & & \multirow{10}{*}{$\begin{array}{l}\text { Elongated renal } \\
\text { papilla } \\
\text { * Large desert } \\
\text { mammals do } \\
\text { not show this } \\
\text { characteristic } \\
\text { (Mbassa 1988) }\end{array}$} & Semidesert & & & \\
\hline & & & - Black-tailed tree rat & Frean et al. 1998 & & \\
\hline & & & Thallomys nigricauda & & & \\
\hline & & & - Salt flat mouse Salinomys & Diaz and Ojeda & & \\
\hline & & & delicatus & 1999 & & \\
\hline & & & Desert & & & \\
\hline & & & - Egyptian gerbil Gerbillus & Khalil and Tawfic & & \\
\hline & & & gerbillus & 1963 & & \\
\hline & & & - Plains viscacha rat & Diaz and Ojeda & & \\
\hline & & & Tympanoctomys barrerae & 1999 & & \\
\hline
\end{tabular}

Systems providing an appropriate adaptive response (behavior, physiology, or morphology); flexibility of traits (flexible or fixed). Fixed traits also include traits that show developmental plasticity during ontogeny. Researchers should identify the relative plasticity of fixed traits in particular environments (i.e., the reaction norm). A list of traits that could confer a fitness advantage under increasing likelihood of droughts, in relation to the three parts of the triquetra. We have included examples of a large- and small-bodied semidesert and desert species for each trait. The final two columns can be used by researchers and nature conservationists to categorize their study species, to identify areas where information is lacking, and to reach conclusions about the relative status of their species. The selected references appear in Appendix 1.

TABLE 2B

The adaptive triquetra system for the environmental stressor food restriction.

\begin{tabular}{|c|c|c|c|c|c|c|}
\hline System & $\begin{array}{c}\text { Nature of } \\
\text { the trait }\end{array}$ & Trait & Example species & $\begin{array}{c}\text { Selected } \\
\text { references }\end{array}$ & $\begin{array}{l}\text { Present in my } \\
\text { study species? }\end{array}$ & $\begin{array}{l}\text { Degree of plasticity } \\
\text { or flexibility? }\end{array}$ \\
\hline \multirow[t]{13}{*}{ Behavior } & Flexible & Stores/caches food/ & Semidesert & & & \\
\hline & & scatter hoards & $\begin{array}{l}\text { - Black-backed jackal Canis } \\
\text { mesomelas }\end{array}$ & Nel 1984 & & \\
\hline & & & $\begin{array}{l}\text { - Giant kangaroo rat } \\
\text { Dipodomys ingens }\end{array}$ & Shaw 1934 & & \\
\hline & & & $\begin{array}{l}\text { Desert } \\
\text { - Desert kit fox Vulpes } \\
\text { macrotis arsipus }\end{array}$ & Cypher 2003 & & \\
\hline & & & $\begin{array}{l}\text { - Wagner's gerbil Gerbillus } \\
\text { dasyurus dasyurus }\end{array}$ & $\begin{array}{l}\text { Hatough-Bouran } \\
\qquad 1990\end{array}$ & & \\
\hline & & Exploits newly & Semidesert & & & \\
\hline & & emergent food & - African striped mouse & Schradin and Pillay & & \\
\hline & & material & Rhabdomys pumilio & 2006 & & \\
\hline & & & - Vicuña Vicugna vicugna & Donadio et al. 2012 & & \\
\hline & & & Desert & & & \\
\hline & & & - Arabian oryx Oryx leucoryx & Ostrowski et al. 2006 & & \\
\hline & & & - Piute ground squirrel & Rickart 1986 & & \\
\hline & & & Spermophilus mollis & & & \\
\hline
\end{tabular}


TABLE 2B

Continued

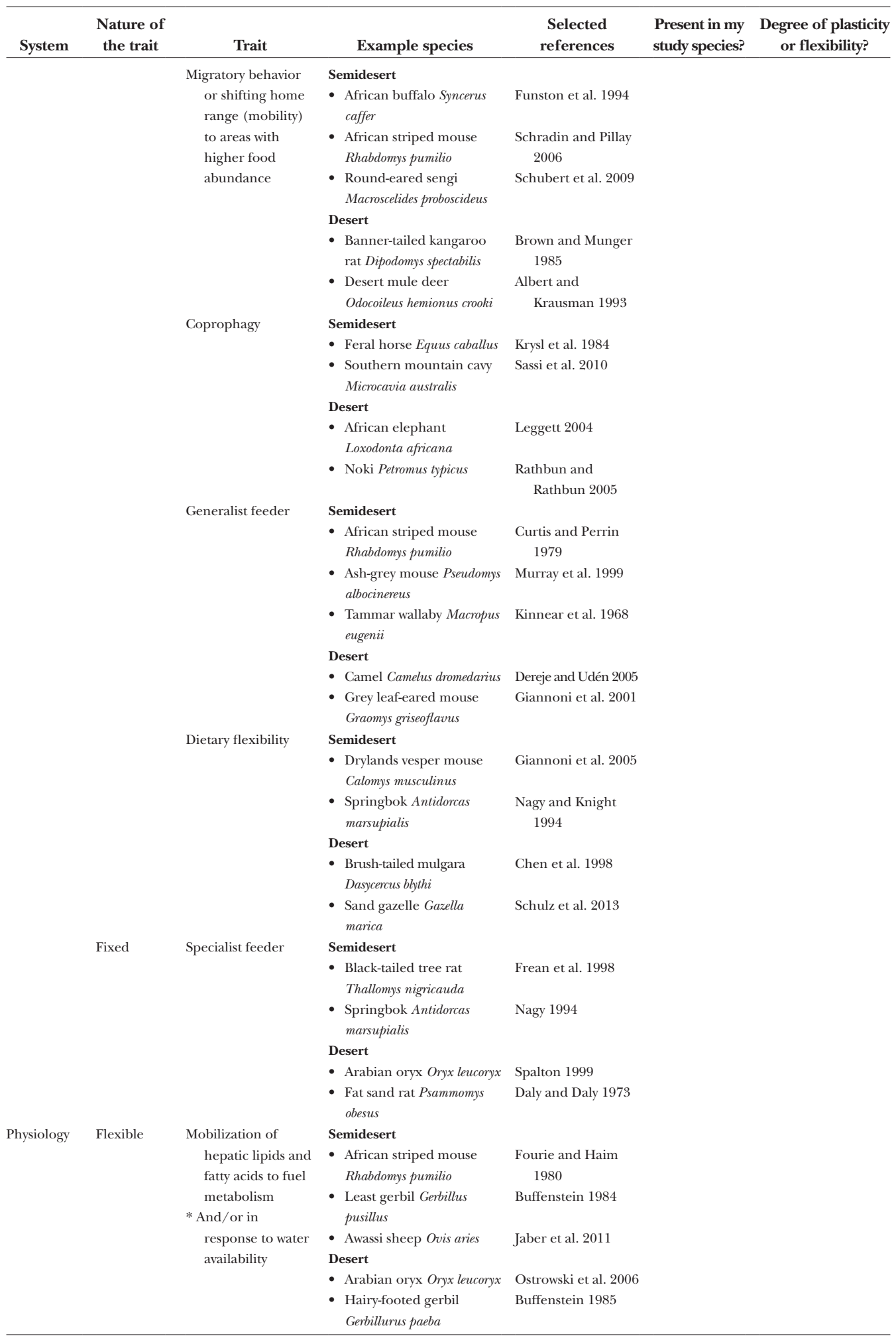


TABLE 2B

Continued

\begin{tabular}{|c|c|c|c|c|c|c|}
\hline System & $\begin{array}{c}\text { Nature of } \\
\text { the trait }\end{array}$ & Trait & Example species & $\begin{array}{c}\text { Selected } \\
\text { references }\end{array}$ & $\begin{array}{l}\text { Present in my } \\
\text { study species? }\end{array}$ & $\begin{array}{c}\text { Degree of plasticity } \\
\text { or flexibility? }\end{array}$ \\
\hline & & Enters torpor (or & Semidesert & & & \\
\hline & & hibernation) & - Grey mouse lemur & Schmid 2001; Schmid & & \\
\hline & & $*$ And/or in & Microcebus murinus & and Speakman 2009 & & \\
\hline & & response to water & - North African elephant & Lovegrove et al. & & \\
\hline & & restriction and & shrew Elephantulus rozeti & 2001 & & \\
\hline & & temperature & Desert & & & \\
\hline & & extremes. & - Round-tailed ground & Hudson 1964 & & \\
\hline & & Information on & squirrel Spermophilus & & & \\
\hline & & large mammals & tereticaudus & & & \\
\hline & & is lacking in the & - Stripe-faced dunnart & Song and Geiser & & \\
\hline & & literature & Sminthopsis macroura & 1997 & & \\
\hline & & Reduced leptin & Semidesert & & & \\
\hline & & secretion in & - Awassi sheep Ovis aries & Jaber et al. 2011 & & \\
\hline & & response to & - Common spiny mouse & Bukovetzky et al. & & \\
\hline & & starvation, & Acomys cahirinus & 2012 & & \\
\hline & & to reduce & - Desert & & & \\
\hline & & mobilization of & - Arabian oryx Oryx leucoryx & Ostrowski et al. 2006 & & \\
\hline & & fatty acid reserves & $\begin{array}{l}\text { Golden spiny mouse } \\
\text { Acomys russatus }\end{array}$ & Gutman et al. 2008 & & \\
\hline & & Ecological leptin & Semidesert & & & \\
\hline & & hypothesis & - African striped mouse & Schradin et al. 2014 & & \\
\hline & & * This dissociation & Rhabdomys pumilio & & & \\
\hline & & between leptin & - Mongolian gerbil Meriones & Zhang and Wang & & \\
\hline & & and fattening is & unguiculatus & 2007 & & \\
\hline & & lacking in the & - Desert & & & \\
\hline & & literature & - Golden spiny mouse & Gutman et al. 2006 & & \\
\hline & & & Acomys russatus & & & \\
\hline & Fixed & Maintenance, & Semidesert & & & \\
\hline & & tolerance, or & - Least gerbil Gerbillus & Buffenstein 1984 & & \\
\hline & & minimal loss of & pusillus & & & \\
\hline & & body mass & $\begin{array}{l}\text { - Springbok Antidorcas } \\
\text { marsupialis }\end{array}$ & Nagy 1994 & & \\
\hline & & & Desert & & & \\
\hline & & & - Camel Camelus & Siebert and & & \\
\hline & & & dromedarius & Macfarlane 1975 & & \\
\hline & & & - Sandy inland & MacMillen and Lee & & \\
\hline & & & mouse Pseudomys & 1967 & & \\
\hline & & & hermannsburgensis & & & \\
\hline \multirow[t]{16}{*}{ Morphology } & Flexible & Flexibility in length/ & Semidesert & & & \\
\hline & & mass of portions & - Burro Equus asinus & Sneddon et al. 2006 & & \\
\hline & & of the gut/ & - Southern mountain cavy & Sassi et al. 2007 & & \\
\hline & & $\begin{array}{l}\text { intestine/and } \\
\text { mass of other vital }\end{array}$ & $\begin{array}{l}\text { Microcavia australis } \\
\text { Desert }\end{array}$ & & & \\
\hline & & organs (e.g., liver, & - Arabian oryx Oryx leucoryx & Ostrowski et al. 2006 & & \\
\hline & & kidneys, cecum) & $\begin{array}{l}\text { - Darwin's leaf-eared } \\
\text { mouse Phyllotis darwini } \\
\text { rupestris }\end{array}$ & Naya et al. 2005 & & \\
\hline & & Storage of fat/lipids & Semidesert & & & \\
\hline & & (i.e., fattening) & - African striped mouse & Schradin and Pillay & & \\
\hline & & & Rhabdomys pumilio & $2005 \mathrm{a}$ & & \\
\hline & & & - Awassi sheep Ovis aries & $\begin{array}{l}\text { Khachadurian et al. } \\
\qquad 1966\end{array}$ & & \\
\hline & & & - Fat-tailed dunnart & Morton 1978 & & \\
\hline & & & Sminthopsis crassicaudata & & & \\
\hline & & & Desert & & & \\
\hline & & & $\begin{array}{l}\text { - Camel Camelus } \\
\text { dromedarius }\end{array}$ & Elkhawad 1992 & & \\
\hline & & & - Golden spiny mouse & Gutman et al. 2006 & & \\
\hline & & & Acomys russatus & & & \\
\hline
\end{tabular}


TABLE 2B

Continued

\begin{tabular}{|c|c|c|c|c|c|c|}
\hline System & $\begin{array}{c}\text { Nature of } \\
\text { the trait }\end{array}$ & Trait & Example species & $\begin{array}{l}\text { Selected } \\
\text { references }\end{array}$ & $\begin{array}{l}\text { Present in my } \\
\text { study species? }\end{array}$ & $\begin{array}{l}\text { Degree of plasticity } \\
\text { or flexibility? }\end{array}$ \\
\hline & \multirow[t]{6}{*}{ Fixed } & Strong digestive & Semidesert & & & \\
\hline & & efficiency & - Degu Octodon degus & $\begin{array}{l}\text { Veloso and } \\
\text { Bozinovic } 1993\end{array}$ & & \\
\hline & & & - Kirk's dik-dik Madoqua kirkii & Hoppe 1977 & & \\
\hline & & & Desert & & & \\
\hline & & & - Arabian oryx Oryx leucoryx & Ostrowski et al. 2006 & & \\
\hline & & & $\begin{array}{l}\text { - Great Basin pocket } \\
\text { mouse Perognathus parvus }\end{array}$ & Schreiber 1979 & & \\
\hline
\end{tabular}

Systems providing an appropriate adaptive response (behavior, physiology, or morphology); flexibility of traits (flexible or fixed). Fixed traits also include traits that show developmental plasticity during ontogeny. Researchers should identify the relative plasticity of fixed traits in particular environments (i.e., the reaction norm). A list of traits that could confer a fitness advantage under increasing likelihood of droughts, in relation to the three parts of the triquetra. We have included examples of a large- and small-bodied semidesert and desert species for each trait. The final two columns can be used by researchers and nature conservationists to categorize their study species, to identify areas where information is lacking, and to reach conclusions about the relative status of their species. The selected references appear in Appendix 1.

WHICH BODY SYSTEM MOUNTS AN APPROPRIATE ADAPTIVE RESPONSE?

The second step of the adaptive triquetra model is to identify which body systems have changed in response to the environmental challenges associated with increasing droughts (Box 2). We expect that all species may use multiple adaptive strategies at the behavioral, physiological, and morphological levels to adapt to, and cope with, the prevailing environment. First, animals may use specific behaviors to avoid harsh environmental conditions. Animals can reduce water stress by choosing to consume water-rich food, by reducing their food intake (thereby minimizing water required for digestion), and/or by reducing respiration to minimize evaporative water loss (Table $2 \mathrm{a}$ ). Animals can reduce food stress by consuming newly emergent food (e.g., plant/insect), by altering the diet to include a wider variety of food types (opportunistic feeders), or by storing or caching food (Table $2 b$ ). To avoid temperature extremes, animals can employ a range of behavioral strategies to minimize overheating, such as utilizing burrows/cover/shade that buffer temperature extremes and also minimize water loss, or altering body posture to minimize exposure to the sun (Tables 2a, b, and c). Altering activity levels by shifting to nocturnal activity is another strategy minimizing exposure to lethal diurnal temperatures, as well as minimizing water loss (Tables 2a and c).

Second, physiological traits of osmoregulation, metabolism, and thermoregulation enable individuals to offset the limited resources of water and food, and to respond to thermal stress (Tables 2a, b, and c). We need to differentiate between physiological mechanisms of the three processes and the physiological markers indicating deviation from the optimal physiological state, which could suggest that the individual is struggling to maintain homeostasis. For example, decreased thyroxine levels could indicate a mechanism to save metabolic energy (Yousef and Johnson 1975), while reduced blood glucose levels might not be an adaptation, but rather a physiological marker of deviation (stress) from the optimal physiological state (McCue 2010).

Recently, the term allostasis has been used to describe the physiological mechanisms that maintain stability (homeostasis of blood glucose, $\mathrm{pH}$, and $\mathrm{O}_{2}$ levels) through change of the osmoregulatory, metabolic, and/or thermoregulatory system (McEwen and Wingfield 2003). Importantly, allostasis depends on the energy availability in the environment, which decreases during droughts, leading to allostasis overload type 1 (energy expenditure to cope with environmental stressors is greater than energy intake; McEwen and 
TABLE 2C

The adaptive triquetra system for the environmental stressor extremes in environmental temperature $\left(\mathrm{T}_{\mathrm{a}}\right)$

\begin{tabular}{|c|c|c|c|c|c|c|}
\hline System & $\begin{array}{c}\text { Nature of } \\
\text { the trait }\end{array}$ & Trait & Example species & $\begin{array}{c}\text { Selected } \\
\text { references }\end{array}$ & $\begin{array}{l}\text { Present in my } \\
\text { study species? }\end{array}$ & $\begin{array}{c}\text { Degree of plasticity } \\
\text { or flexibility? } \\
\end{array}$ \\
\hline \multirow[t]{35}{*}{ Behavior } & Flexible & Utilizes burrows/ & Semidesert & & & \\
\hline & & $\begin{array}{l}\text { nests, cover, or } \\
\text { retreats to shade }\end{array}$ & $\begin{array}{l}\text { - African striped mouse } \\
\text { Rhabdomys pumilio }\end{array}$ & Schradin 2005 & & \\
\hline & & when available & $\begin{array}{l}\text { - Giant kangaroo rat } \\
\text { Dipodomys ingens }\end{array}$ & Randall 1997 & & \\
\hline & & & $\begin{array}{l}\text { - Southern hairy-nosed } \\
\text { wombat Lasiorhinus latifrons }\end{array}$ & Walker et al. 2007 & & \\
\hline & & & Desert & & & \\
\hline & & & $\begin{array}{l}\text { - Euro Macropus robustus } \\
\text { erubescens }\end{array}$ & $\begin{array}{l}\text { Dawson and Brown } \\
1970\end{array}$ & & \\
\hline & & & $\begin{array}{l}\text { - Sundevall's jird Meriones } \\
\text { crassus crassus }\end{array}$ & Lewis et al. 1965 & & \\
\hline & & Utilizes substrate & Semidesert & & & \\
\hline & & $\begin{array}{l}\text { surface for } \\
\text { conductance of }\end{array}$ & $\begin{array}{l}\text { - African striped mouse } \\
\text { Rhabdomys pumilio }\end{array}$ & Schradin 2006 & & \\
\hline & & body heat & - Cape ground squirrel & Marsh et al. 1978 & & \\
\hline & & * Information is & Xerus inauris & & & \\
\hline & & $\begin{array}{l}\text { lacking for large } \\
\text { semidesert species }\end{array}$ & - Suricate Suricata suricatta & $\begin{array}{l}\text { Hinton and Dunn } \\
1967\end{array}$ & & \\
\hline & & & Desert & & & \\
\hline & & & $\begin{array}{l}\text { - Desert mule deer } \\
\text { Odocoileus hemionus crooki }\end{array}$ & Cain et al. 2006 & & \\
\hline & & & $\begin{array}{l}\text { White-tailed antelope } \\
\text { squirrel Ammospermophilus } \\
\text { leucurus }\end{array}$ & $\begin{array}{l}\text { Chappell and } \\
\text { Bartholomew } \\
\text { 1981a }\end{array}$ & & \\
\hline & & Uses body parts to & Semidesert & & & \\
\hline & & facilitate shading & $\begin{array}{l}\text { - Cape ground squirrel } \\
\text { Xerus inauris }\end{array}$ & Bennett et al. 1984 & & \\
\hline & & & $\begin{array}{l}\text { - Springbok Antidorcas } \\
\text { marsupialis }\end{array}$ & Fuller et al. 2005 & & \\
\hline & & & Desert & & & \\
\hline & & & $\begin{array}{l}\text { - Camel Camelus } \\
\text { dromedarius }\end{array}$ & $\begin{array}{l}\text { Ouajd and Kamel } \\
2009\end{array}$ & & \\
\hline & & & - White-tailed antelope & Chappell and & & \\
\hline & & & squirrel Ammospermophilus & Bartholomew & & \\
\hline & & & leucurus & $1981 b$ & & \\
\hline & & Activity variable or & Semidesert & & & \\
\hline & & polyphasic & $\begin{array}{l}\text { - Mongolian gerbil Meriones } \\
\text { unguiculatus }\end{array}$ & Lewis et al. 1965 & & \\
\hline & & & $\begin{array}{l}\text { Black wildebeest } \\
\text { Connochaetes gnou }\end{array}$ & Maloney et al. 2005 & & \\
\hline & & & Desert & & & \\
\hline & & & - Arabian oryx Oryx leucoryx & Stewart 1963 & & \\
\hline & & & $\begin{array}{l}\text { - Lybian jird Meriones } \\
\text { libycus }\end{array}$ & Aulagnier et al. 2008 & & \\
\hline & & Primary activity- & Semidesert & & & \\
\hline & & crepuscular & $\begin{array}{l}\text { - African wild dog Lycaon } \\
\text { pictus }\end{array}$ & Woodroffe 2011 & & \\
\hline & & & $\begin{array}{l}\text { - Bush karoo rat Otomys } \\
\text { unisulcatus }\end{array}$ & $\begin{array}{l}\text { Vermeulen and Nel } \\
1988\end{array}$ & & \\
\hline & & & Desert & & & \\
\hline & & & - King jird Meriones rex & Alagaili et al. 2013 & & \\
\hline & & & $\begin{array}{l}\text { - Red kangaroo Macropus } \\
\text { rufus }\end{array}$ & Dawson et al. 1975 & & \\
\hline
\end{tabular}


TABLE 2C

Continued

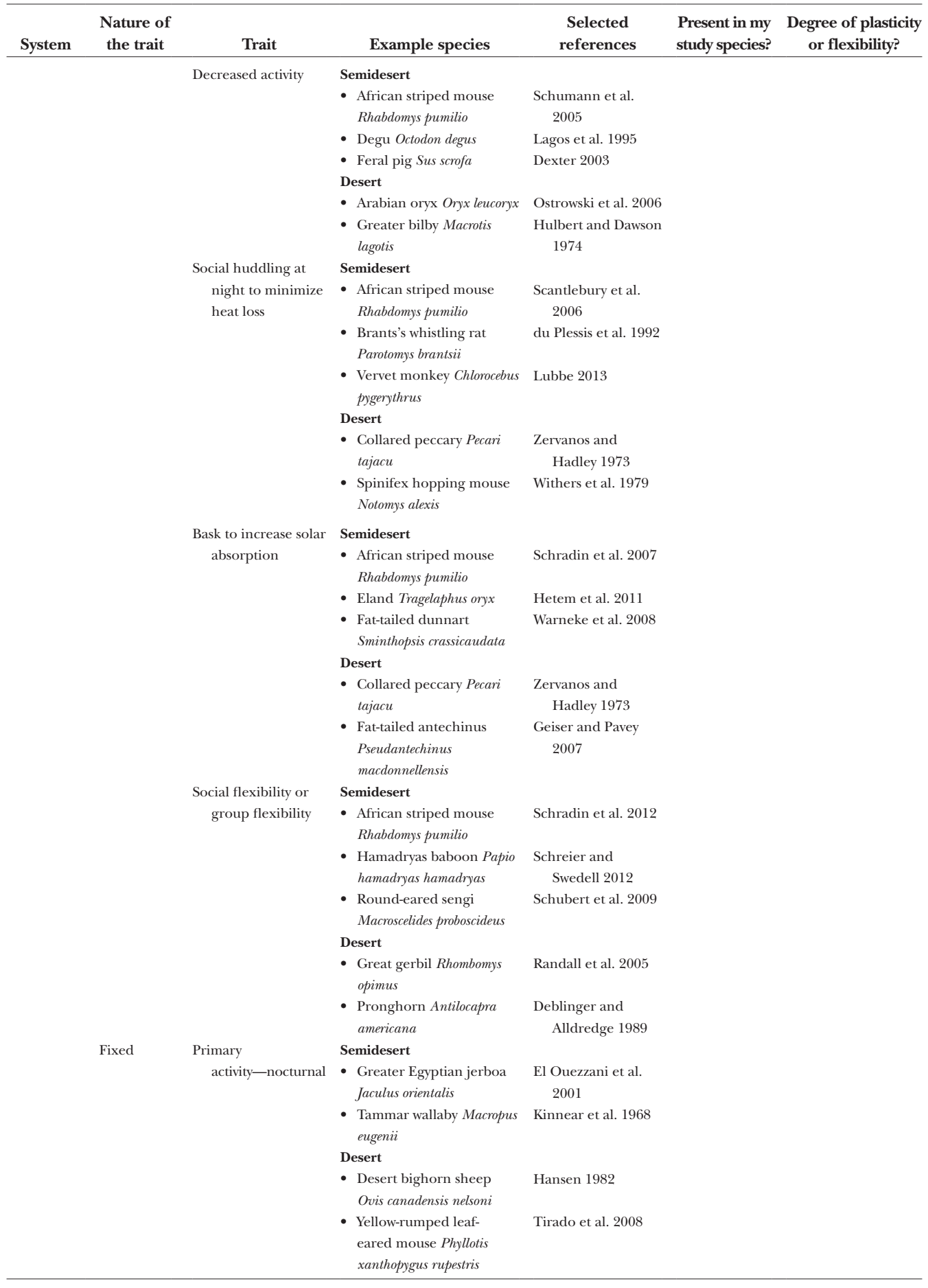


TABLE 2C

Continued

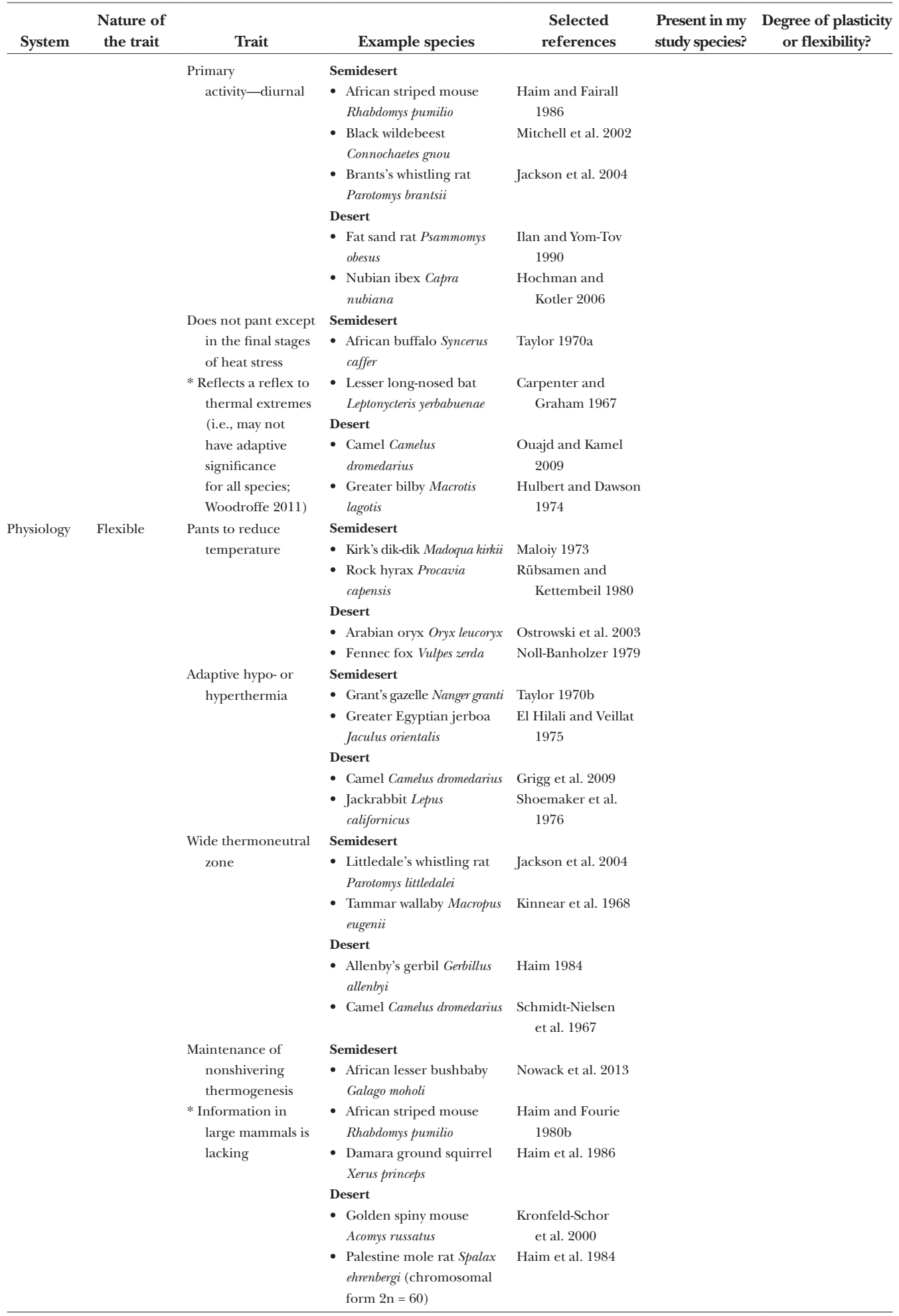


TABLE 2C

Continued

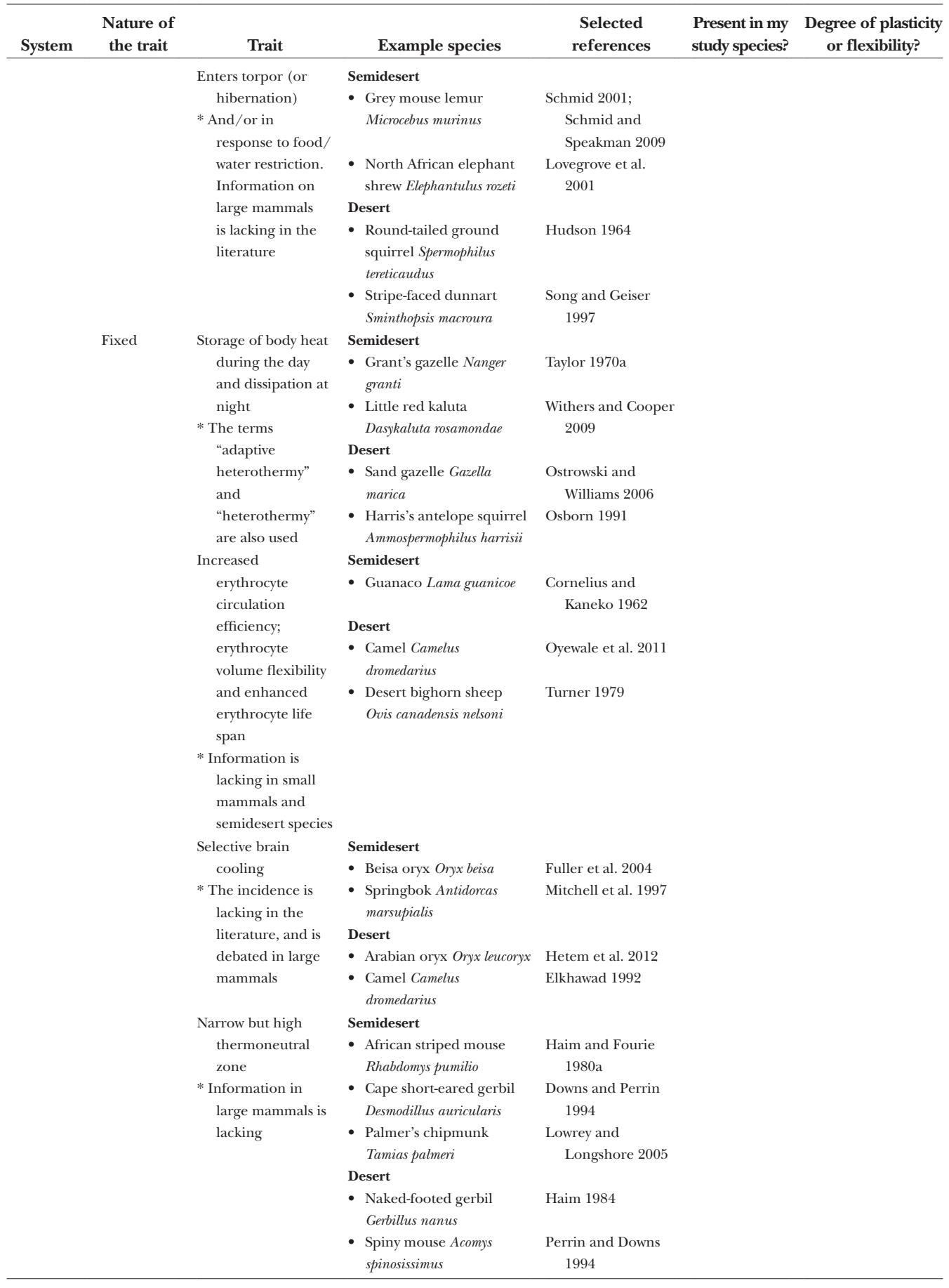


TABLE 2C

Continued

\begin{tabular}{|c|c|c|c|c|c|c|}
\hline System & $\begin{array}{c}\text { Nature of } \\
\text { the trait }\end{array}$ & Trait & Example species & $\begin{array}{c}\text { Selected } \\
\text { references }\end{array}$ & $\begin{array}{l}\text { Present in my } \\
\text { study species? }\end{array}$ & $\begin{array}{c}\text { Degree of plasticity } \\
\text { or flexibility? }\end{array}$ \\
\hline & & $\begin{array}{l}\text { High thermal } \\
\text { conductance }\end{array}$ & $\begin{array}{l}\text { Semidesert } \\
\text { - African striped mouse } \\
\text { Rhabdomys pumilio } \\
\text { - Awassi sheep Ovis aries } \\
\text { - Western barred bandicoot } \\
\text { Perameles bougainville } \\
\text { bougainville } \\
\text { Desert } \\
\text { - Collared peccary Pecari } \\
\text { tajacu } \\
\text { - Desert kit fox Vulpes } \\
\text { macrotis arsipus }\end{array}$ & $\begin{array}{l}\text { Haim and Fairall } \\
1986 \\
\text { Degen and Shkolnik } \\
1978 \\
\text { Larcombe and } \\
\text { Withers } 2006 \\
\\
\text { Zervanos and } \\
\text { Hadley } 1973 \\
\text { Golightly and } \\
\text { Ohmart } 1983\end{array}$ & & \\
\hline \multirow[t]{8}{*}{ Morphology } & Flexible & $\begin{array}{l}\text { Limited } \\
\text { subcutaneous } \\
\text { fat deposition or } \\
\text { localized storage }\end{array}$ & $\begin{array}{l}\text { Semidesert } \\
\text { - Boer goat Capra aegagrus } \\
\text { hircus } \\
\text { - Fat-tailed dunnart } \\
\text { Sminthopsis crassicaudata } \\
\text { Desert } \\
\text { - Camel Camelus } \\
\text { dromedarius } \\
\text { - Soda Spring Valley } \\
\text { kangaroo mouse } \\
\text { Microdipodops pallidus }\end{array}$ & $\begin{array}{l}\text { Casey and van } \\
\text { Niekerk } 1988 \\
\text { Morton } 1978 \\
\text { Young } 1976 \\
\text { Bartholomew and } \\
\text { MacMillen } 1961\end{array}$ & & \\
\hline & Fixed & $\begin{array}{l}\text { Bipedal locomotion } \\
\text { (or tendency) }\end{array}$ & $\begin{array}{l}\text { Semidesert } \\
\text { - Great jerboa Allactaga } \\
\quad \text { major }\end{array}$ & $\begin{array}{l}\text { Schmidt-Nielsen and } \\
\text { Schmidt-Nielsen } \\
1952\end{array}$ & & \\
\hline & & & $\begin{array}{l}\text { - Tammar wallaby Macropus } \\
\text { eugenii } \\
\text { Desert }\end{array}$ & $\begin{array}{l}\text { Baudinette et al. } \\
\qquad 1992\end{array}$ & & \\
\hline & & & $\begin{array}{l}\text { - Dusky hopping mouse } \\
\text { Notomys fuscus }\end{array}$ & $\begin{array}{l}\text { Schmidt-Nielsen and } \\
\text { Schmidt-Nielsen } \\
1952\end{array}$ & & \\
\hline & & & $\begin{array}{l}\text { - Red kangaroo Macropus } \\
\text { rufus }\end{array}$ & $\begin{array}{l}\text { Dawson and Taylor } \\
1973\end{array}$ & & \\
\hline & & Short coarse pelage & $\begin{array}{l}\text { Semidesert } \\
\text { - African buffalo Syncerus } \\
\text { caffer } \\
\text { - Gulf coast kangaroo rat } \\
\text { Dipodomys compactus } \\
\text { Desert } \\
\text { - Arabian oryx Oryx leucoryx } \\
\text { - Round-tailed ground } \\
\text { squirrel Spermophilus } \\
\text { tereticaudus }\end{array}$ & $\begin{array}{l}\text { Marai and Haeeb } \\
\quad 2010 \\
\text { Baumgardner } 1991 \\
\text { Stewart } 1963 \\
\text { Walsberg } 1988\end{array}$ & & \\
\hline & & $\begin{array}{l}\text { Light colored pelage } \\
\text { for reflecting } \\
\text { solar radiation } \\
\text { and reducing heat } \\
\text { uptake }\end{array}$ & $\begin{array}{l}\text { Semidesert } \\
\text { - Panamint kangaroo rat } \\
\text { Dipodomys panamintinus } \\
\text { - Springbok Antidorcas } \\
\text { marsupialis } \\
\text { Desert }\end{array}$ & $\begin{array}{l}\text { Intress and Best } \\
\qquad 1990 \\
\text { Mitchell et al. } 1997\end{array}$ & & \\
\hline & & & $\begin{array}{l}\text { - Desert bighorn sheep } \\
\text { Ovis canadensis nelsoni } \\
\text { - Eastern Patagonian } \\
\text { laucha Eligmodontia typus }\end{array}$ & $\begin{array}{l}\text { McCutchen } 1981 \\
\text { Giannoni et al. } 2001\end{array}$ & & \\
\hline
\end{tabular}


TABLE 2C

Continued

\begin{tabular}{|c|c|c|c|c|c|c|}
\hline System & $\begin{array}{c}\text { Nature of } \\
\text { the trait }\end{array}$ & Trait & Example species & $\begin{array}{c}\text { Selected } \\
\text { references }\end{array}$ & $\begin{array}{l}\text { Present in my } \\
\text { study species? }\end{array}$ & $\begin{array}{c}\text { Degree of plasticity } \\
\text { or flexibility? }\end{array}$ \\
\hline & & \multirow[t]{10}{*}{ Dark pigmented skin } & Semidesert & & & \\
\hline & & & - African buffalo Syncerus & Marai and Haeeb & & \\
\hline & & & caffer & 2010 & & \\
\hline & & & - African striped mouse & Timm and Kermott & & \\
\hline & & & Rhabdomys pumilio & 1982 & & \\
\hline & & & - Damara ground squirrel & Waterman and & & \\
\hline & & & Xerus princeps & Herron 2004 & & \\
\hline & & & Desert & & & \\
\hline & & & $\begin{array}{l}\text { - Addax Addax } \\
\text { nasomaculatus }\end{array}$ & Portas et al. 2003 & & \\
\hline & & & $\begin{array}{l}\text { - Golden spiny mouse } \\
\text { Acomys russatus }\end{array}$ & $\begin{array}{l}\text { Haim and Rozenfeld } \\
1995\end{array}$ & & \\
\hline & & \multirow{7}{*}{$\begin{array}{l}\text { Presence of a carotid } \\
\text { rete } \\
\text { * Information is } \\
\text { lacking for small } \\
\text { mammals }\end{array}$} & Semidesert & & & \\
\hline & & & - Kirk's dik-dik Madoqua & Kamau et al. 1984 & & \\
\hline & & & kirkii & & & \\
\hline & & & $\begin{array}{l}\text { - Springbok Antidorcas } \\
\text { marsupialis }\end{array}$ & Mitchell et al. 2002 & & \\
\hline & & & Desert & & & \\
\hline & & & $\begin{array}{l}\text { - Camel Camelus } \\
\text { dromedarius }\end{array}$ & Elkhawad 1992 & & \\
\hline & & & $\begin{array}{l}\text { - Pronghorn Antilocapra } \\
\text { americana }\end{array}$ & Mitchell et al. 2009 & & \\
\hline & & \multirow{11}{*}{$\begin{array}{c}\text { Nasal countercurrent } \\
\text { exchange system } \\
\text { * This concurrently } \\
\text { provides a benefit } \\
\text { against water loss }\end{array}$} & Semidesert & & & \\
\hline & & & - Giraffe Giraffa & Langman et al. 1979 & & \\
\hline & & & camelopardalis & & & \\
\hline & & & - Little red kaluta & Withers and Cooper & & \\
\hline & & & Dasykaluta rosamondae & 2009 & & \\
\hline & & & Desert & & & \\
\hline & & & - Camel Camelus & Schmidt-Nielsen & & \\
\hline & & & dromedarius & et al. $1981 b$ & & \\
\hline & & & - Merriam's kangaroo rat & Jackson and & & \\
\hline & & & Dipodomys merriami & Schmidt-Nielsen & & \\
\hline & & & & 1964 & & \\
\hline
\end{tabular}

Systems providing an appropriate adaptive response (behavior, physiology, or morphology); flexibility of traits (flexible or fixed). Fixed traits also include traits that show developmental plasticity during ontogeny. Researchers should identify the relative plasticity of fixed traits in particular environments (i.e., the reaction norm). A list of traits that could confer a fitness advantage under increasing likelihood of droughts, in relation to the three parts of the triquetra. We have included examples of a large- and small-bodied semidesert and desert species for each trait. The final two columns can be used by researchers and nature conservationists to categorize their study species, to identify areas where information is lacking, and to reach conclusions about the relative status of their species. The selected references appear in Appendix 1.

Wingfield 2003). Whether this leads to permanent damage and pathology, and finally death, can be modeled using the reactive scope model, which takes into account the short- and long-term effects of physiological mediators of allostasis (Romero et al. 2009; Romero 2012).

Osmoregulation is regulated by the secretion of several hormones, especially AVP, aldosterone, and renin (Finberg et al. 1978; Ben Goumi et al. 1993), which regulate water reabsorption in the kidneys and water excretion via urine. Several physiolog- ical markers can indicate a deviation from osmotic homeostasis, such as decreased plasma volume (Siebert and Macfarlane 1975; Ouajd and Kamel 2009) or increased concentration of proteins and sugars (Ouajd and Kamel 2009). Metabolism is regulated by corticosterone and thyroxine, mobilizing hepatic lipids and fatty acids in response to food restriction (Ostrowski et al. 2006; Ouajd and Kamel 2009). Thermoregulation is maintained by corticosterone, dexamethasone, and prednisolone, as well as sodium, and their influence on the sympathetic ner- 
vous system (Maickel et al. 1967). Thermoregulatory enhancements are indicated by increased erythrocyte circulation efficiency and changes in erythrocyte volume flexibility (Ouajd and Kamel 2009), which would facilitate oxygen circulation in the body.

Third, morphological structures, both internal and external, can help an animal to cope with water and food shortage, as well as high $\mathrm{T}_{\mathrm{a}}$ (Tables 2a, b, and c). Kidney morphology, in particular long loops of Henle, increases water reabsorption and minimizes water loss by increasing urine concentration (Ouajd and Kamel 2009). Organ size and volume can be altered in response to food restriction to minimize the energetic costs of maintaining those organs (Ostrowski et al. 2006). Body size itself can have a profound effect on resilience to climate, and can change both plastically or due to evolutionary adaptation (Brown and Brown 1998). In mammals, paleontologists have observed dwarfing (reduction in body size) during the Paleocene-Eocene boundary, a period of global warming (Gingerich 2006), and dwarfing might also occur in extant mammals in response to increasing $\mathrm{T}_{\mathrm{a}}$. Similarly, pelage color and pattern, and skin color can assist in thermoregulation, minimizing solar absorption and increasing solar radiation (Stewart 1963; Haim and Rozenfeld 1995).

\section{HOW FLEXIBLE IS THE TRAIT?}

The final stage of the adaptive triquetra model is to establish the flexibility of the trait under increasing drought conditions (Box 2). Specialized adaptations evolve in response to strong selection pressures imposed by particular habitats. These adaptations are likely to be species-specific because different species adopt different strategies, as well as a combination of strategies, for survival and reproduction under challenging environmental conditions. Furthermore, these adaptations are relatively fixed, with limited flexibility. Specialized adaptations, such as the carotid rete utilized in brain cooling, enables individuals of some species to cope with increasing heat load (Mitchell et al. 2002). In sum, specialized adaptations are of little interest in establishing how a nondesert-adapted species would respond to the increasing frequency of droughts, because such species will not have specialized adaptations.

Traits that show adaptive developmental plasticity can vary between individuals due to environmental factors. However, although developmentally plastic traits are flexible during early life stages, they are generally fixed by adulthood (Piersma and van Gils 2010). Adaptive developmental plasticity is thus an important determinant of resilience to drought. Essentially, every fixed trait can be categorized according to the nature and degree of its developmental plasticity, also known as a reaction norm (Cassidy et al. 2014). This reaction norm can be narrow, with a slope close to zero (totally fixed trait), or it can be broad. Here, we include traits that show adaptive developmental plasticity as fixed traits, because they are not flexible in adults (Tables $2 \mathrm{a}, \mathrm{b}$, and $\mathrm{c}$ ). As a consequence, to determine the resilience to droughts by a species, the level of adaptive developmental plasticity of every fixed trait should be estimated. Broad adaptive developmental plasticity indicates a greater likelihood that a generation exposed to droughts during early development (or to environmental stimuli predicting droughts) will develop traits enabling resilience to droughts.

General adaptations evolve in response to fluctuating and dynamic selection pressures in multiple habitats and are likely to be common among most (if not all) mammals. For example, all mammals secrete AVP from the pituitary to regulate water reabsorption in the kidneys (Acher 1993). Many general adaptations are likely to be phenotypically flexible. Exaptations must also be considered here because their utilization in the current context is flexible, even if the trait evolved as a specialized adaptation in another context. Recent evidence from the available vertebrate literature suggests that most phenotypic responses to climate change and increased droughts would be due to the flexibility of traits (Canale and Henry 2010). There- 
fore, we suggest that identifying flexible traits representing general adaptations and exaptations of nondesert-adapted species is vital for determining whether a species has the potential to persist under increasing drought conditions (Tables 2a, b, and c).

\section{Using the Adaptive Triquetra to Estimate Species Resilience or Vulnerability to Drought}

We have attempted to summarize all known traits of the adaptive triquetra that mammals could use to cope with droughts (Tables 2a, b, and c). These can be used by ecologists and nature conservationists to assess the resilience or vulnerability of one or several species to drought. These tables reflect the variety of traits and species possessing these traits. Currently, in most cases, more research on a specific species would be required by ecologists/nature conservationists to accurately estimate the resilience to drought by a particular species. The tables enable a comparison to be made between different traits, as well as between different large- and/or small-bodied species. They provide a step-by-step approach that could help in making decisions on conservation action, especially of which species to focus on, and which of the three stressors is relevant. For example, for species A it might be most important to offer water at artificial water points during droughts, although for species B food shortage could be more important, so supplemental food should be the priority.

We have planned Tables 2a, b, and c in such a manner that they can be directly applied. In the second to last column, one can mark whether or not a specific trait is present in a species. In the last column, the flexibility of that trait for that species can be estimated. These two columns provide the first overview for a specific species and will give some indication of how resilient or vulnerable it could be. Nonetheless, we realize that, in nearly all cases, filling in these tables will generate more questions than answer the critical question of how resilient a species is to droughts. Thus, one conclusion is that to assess drought resilience of a species, a detailed understanding of the biology and evolutionary history of the species is the requisite first step prior to largescale decision-making processes.

One important aspect not covered by this process is the environment. By definition, drought occurs when the current precipitation falls significantly below the long-term mean of a defined area, leading to water shortage (Dai 2011). Thus, droughts can differ dramatically in intensity and duration, and a population that can cope well with, for example, a $30 \%$ reduction of precipitation over a few months, might not survive a $60 \%$ reduction in precipitation over a longer period. In addition, a population's habitat may provide suitable microclimatic refugia that could facilitate persistence, but not the habitat of another population of the same species. However, it is important to understand the complexity of the species first, and then focus on the environment and habitat later, as the biology of an animal will determine its vulnerability, while the modulating role of the environment may promote or hinder resilience.

\section{Concluding Remarks:}

The Importance of FleXibility

Phenotypic flexibility, rather than future evolutionary adaptation, will most likely facilitate adaptive responses to climate change and increased droughts in the short term (Canale and Henry 2010), which in the long term might lead to evolutionary adaptation (Lind et al. 2015; Scheiner et al. 2015). Identifying those traits that promote persistence in a period of change, as well as understanding the degree of their flexibility, is crucial for assessing whether or not a species will persist under increased frequency and/or periodicity of droughts. In addition to flexibility, resilience might also arise because of exaptation. The concept of exaptation has been criticized as not being useful to understand how species are successful in their current environment (Larson et al. 2013). Yet, the concept might be useful for understanding whether and how species will be able to cope with rapid global change because exaptations could provide important benefits for spe- 
cies not currently accustomed to drought conditions.

Phenotypic flexibility operates at the individual rather than at the population level (Rymer et al. 2013), so the ability of species to cope with change will depend largely on the flexibility of its individuals. In addition, individuals that persist and reproduce transmit genes for trait flexibility to their offspring, and flexibility can be a strong driver of phenotypic evolution (Piersma and van Gils 2010; Standen et al. 2014). Thus, in the mid to long term, these traits, as well as the ability to be flexible, could become fixed through evolutionary adaptation, becoming general or specialized adaptations. However, because phenotypic flexibility can be costly, it is important to study to what degree those traits that are phenotypically flexible in order to establish the limits of this plasticity in promoting persistence.

To understand which traits could promote species persistence to increased periodicity of droughts and increased aridification, we should focus on those species currently inhabiting semideserts because they are likely to possess a suite of existing traits that could be advantageous during droughts and that could be present in species from nondesert environments, in contrast to specialized traits of desert species. Comparative assessment of these species will facilitate identification of traits that could provide fitness advantages for other species encountering increasingly drier conditions. Furthermore, although a species may have a suite of existing phenotypic adaptations or exaptations to droughts, the interaction with other species in its environment, its habitat requirements, amount of available habitat, and human persecution/exploitation will all influence its persistence. Future empirical studies and conservation programs will test the usefulness and applicability of the adaptive triquetra and possibly modify it, enabling us to better predict which populations are vulnerable to drought-related extinction.

\section{ACKNOWLEDGMENTS}

The suggestions provided by the editor and two anonymous reviewers greatly improved the manuscript. We are grateful for support by the University of the Witwatersrand (Neville Pillay), James Cook University (Tasmin L. Rymer), the Université de Strasbourg's Institute for Advanced Study (Carsten Schradin), and the CNRS (Carsten Schradin).

\section{REFERENCES}

Acher R. 1993. Neurohypophysial peptide systems: processing, machinery, hydroosmotic regulation, adaptation and evolution. Regulatory Peptides 45:1-13.

Acocks J. P. H. 1988. Veld types of South Africa. Memoirs of the Botanical Survey of South Africa 57:1-146.

Alley R. B., Marotzke J., Nordhaus W. D., Overpeck J. T., Peteet D. M., Pielke R. A. Jr., Pierrehumbert R. T., Rhines P. B., Stocker T. F., Talley L. D., Wallace J. M. 2003. Abrupt climate change. Science 299:2005-2010.

Baldwin J. M. 1896. A new factor in evolution. American Naturalist 30:441-451.

Bale T. L. 2015. Epigenetic and transgenerational reprogramming of brain development. Nature Reviews Neuroscience 16:332-344.

Baum D. A., Larson A. 1991. Adaptation reviewed: a phylogenetic methodology for studying character macroevolution. Systematic Zoology 40:1-18.

Ben Goumi M., Riad F., Giry J., de la Farge F., Safwate A., Davicco M.-J., Barlet J.-P. 1993. Hormonal control of water and sodium in plasma and urine of camels during dehydration and rehydration. General and Comparative Endocrinology 89:378-386.
Black R., Bennett S. R. G., Thomas S. M., Beddington J. R. 2011. Climate change: migration as adaptation. Nature 478:447-449.

Boroda R., Matmon A., Amit R., Haviv I., Arnold M., Aumaître G., Bourlès D. L., Keddadouche K., Eyal Y., Enzel Y. 2014. Evolution and degradation of flat-top mesas in the hyper-arid Negev, Israel revealed from ${ }^{10} \mathrm{Be}$ cosmogenic nuclides. Earth Surface Processes and Landforms 39:1611-1621.

Bozinovic F., Contreras L. C. 1990. Basal rate of metabolism and temperature regulation of two desert herbivorous octodontid rodents: Octomys mimax and Tympanoctomys barrerae. Oecologia 84:567-570.

Breed M. F., Ottewell K. M., Gardner M. G., Lowe A. J. 2011. Clarifying climate change adaptation responses for scattered trees in modified landscapes. Iournal of Applied Ecology 48:637-641.

Brown C. R., Brown M. B. 1998. Intense natural selection on body size and wing and tail asymmetry in cliff swallows during severe weather. Evolution 52:1461-1475.

Cahill A. E., Aiello-Lammens M. E., Fisher-Reid M. C., Hua X., Karanewsky C. J., Ryu H. Y., Sbeglia G. C., 
Spagnolo F., Waldron J. B., Warsi O., Wiens J. J. 2013. How does climate change cause extinction? Proceedings of the Royal Society B: Biological Sciences 280:2012890.

Canale C. I., Henry P.-Y. 2010. Adaptive phenotypic plasticity and resilience of vertebrates to increasing climatic unpredictability. Climate Research 43:135-147.

Cassidy E. J., Bath E., Chenoweth S. F., Bonduriansky R. 2014. Sex-specific patterns of morphological diversification: evolution of reaction norms and static allometries in neriid flies. Evolution 68:368-383.

Champagne F. A. 2013. Epigenetics and developmental plasticity across species. Developmental Psychobiology 55:33-41.

Champagne F. A., Rissman E. F. 2011. Behavioral epigenetics: a new frontier in the study of hormones and behavior. Hormones and Behavior 59:277-278.

Charmandari E., Tsigos C., Chrousos G. 2005. Endocrinology of the stress response. Annual Review of Physiology 67:259-284.

Charmantier A., McCleery R. H., Cole L. R., Perrins C., Kruuk L. E. B., Sheldon B. C. 2008. Adaptive phenotypic plasticity in response to climate change in a wild bird population. Science 320:800-803.

Charney J., Quirk W. J., Chow S.-H., Kornfield J. 1977. A comparative study of the effects of albedo change on drought in semi-arid regions. Journal of the Atmospheric Sciences 34:1366-1385.

Chaves M. M., Maroco J. P., Pereira J. S. 2003. Understanding plant responses to drought-from genes to the whole plant. Functional Plant Biology 30:239-264.

Chevin L.-M. 2013. Genetic constraints on adaptation to a changing environment. Evolution 67: 708-721.

Coddington J. A. 1994. The roles of homology and convergence in studies of adaptation. Pages 53-78 in Phylogenetics and Ecology, edited by P. Eggleton and R. I. Vane-Wright. Linnean Society Symposium Series, Number 17. London (United Kingdom): Academic Press.

Dai A. 2011. Drought under global warming: a review. Wilev Interdisciplinary Reviews: Climate Change 2:45-65.

de Wit P., Palumbi S. R. 2013. Transcriptome-wide polymorphisms of red abalone (Haliotis rufescens) reveal patterns of gene flow and local adaptation. Molecular Ecology 22:2884-2897.

DeWitt T. J., Sih A., Wilson D. S. 1998. Costs and limits of phenotypic plasticity. Trends in Ecology and Evolution 13:77-81.

Dochtermann N. A., Schwab T., Sih A. 2015. The contribution of additive genetic variation to personality variation: heritability of personality. Proceedings of the Roval Society B: Biological Sciences 282:20142201.
Dukas R. 1999. Costs of memory: ideas and predictions. Iournal of Theoretical Biology 197:41-50.

Elkhawad A. O. 1992. Selective brain cooling in desert animals: the camel (Camelus dromedarius). Comparative Biochemistry and Phvsiology Part A: Physiology 101:195-201.

Etterson J. R., Shaw R. G. 2001. Constraint to adaptive evolution in response to global warming. Science 294:151-154.

Fahrig L. 2003. Effects of habitat fragmentation on biodiversity. Annual Review of Ecology and Systematics 34:487-515.

Faye B. 1997. Le guide de l'élevage du dromadaire. Libourne (France): Sanofi Santé Nutrition Animale.

Finberg J. P., Yagil R., Berlyne G. M. 1978. Response of the renin-aldosterone system in the camel to acute dehydration. Iournal of Applied Physiology 44: 926-930.

Galbraith H., Jones R., Park R., Clough J., HerrodJulius S., Harrington B., Page G. 2002. Global climate change and sea level rise: potential losses of intertidal habitat for shorebirds. Waterbirds 25:173-183.

Ghalambor C. K., McKay J. K., Carroll S. P., Reznick D. N. 2007. Adaptive versus non-adaptive phenotypic plasticity and the potential for contemporary adaptation in new environments. Functional Ecology 21:394-407.

Gingerich P. D. 2006. Environment and evolution through the Paleocene-Eocene thermal maximum. Trends in Ecology and Evolution 21:246-253.

Gomulkiewicz R., Houle D. 2009. Demographic and genetic constraints on evolution. American Naturalist 174:E218-E229.

Gonzalez A., Ronce O., Ferriere R., Hochberg M. E. 2013. Evolutionary rescue: an emerging focus at the intersection between ecology and evolution. Philosophical Transactions of the Royal Society B: Biological Sciences 368:20120404.

Gould S. J., Lewontin R. C. 1979. The spandrels of San Marco and the Panglossian paradigm: a critique of the adaptationist programme. Proceedings of the Roval Societv B: Biological Sciences 205:581-598.

Gould S. J., Vrba E. S. 1982. Exaptation-a missing term in the science of form. Paleobiology 8:4-15.

Grubbs D. E. 1980. Tritiated water turnover in freeliving desert rodents. Comparative Biochemistry and Phvsiology Part A: Physiology 66:89-98.

Haim A., Rozenfeld F. M. 1995. Temporal segregation in co-existing Acomys species: the possible role of nest site. Journal of Arid Environments 29:505-509.

Harley C. D. G. 2011. Climate change, keystone predation, and biodiversity loss. Science 334:1124-1127.

Hetem R. S., Strauss W. M., Fick L. G., Maloney S. K., Meyer L. C. R., Fuller A., Shobrak M., Mitchell D. 2012. Selective brain cooling in Arabian oryx (Oryx leucoryx): a physiological mechanism for 
coping with aridity? Iournal of Experimental Biology 215:3917-3924.

Hodgson D., McDonald J. L., Hosken D. J. 2015. What do you mean, "resilient"? Trends in Ecology and Evolution 30:503-506.

Hoffman J. 2014. Physiological response of Bufo viridis (Laurenti, 1768) populations across an aridity gradient. Alytes-International Journal of Batrachology 30:33-41.

Hoffmann A. A., Sgrò C. M. 2011. Climate change and evolutionary adaptation. Nature 470:479-485.

Hughes T. P., Rodrigues M. J., Bellwood D. R., Ceccarelli D., Hoegh-Guldberg O., McCook L., Moltschaniwskyj N., Pratchett M. S., Steneck R. S., Willis B. 2007. Phase shifts, herbivory, and the resilience of coral reefs to climate change. Current Biology 17:360-365.

IPCC 2007. Climate Change 2007: The Physical Science Basis: Contribution of Working Group I to the Fourth Assessment Report of the Intergovernmental Panel on Climate Change, edited by S. D. Solomon, Q. M. Manning, Z. Chen, M. Marquis, K. B. Averyt, M. Tignor, and H. L. Miller. Cambridge (United Kingdom): Cambridge University Press.

IPCC 2013. Climate Change 2013: The Physical Science Basis: Working Group I Contribution to the Fifth Assessment Report of the Intergovernmental Panel on Climate Change, edited by T. F. Stocker, D. Qin, G. K. Plattner, M. M. B. Tignor, S. K. Allen, J. Boschung, A. Nauels, Y. Xia, V. Bex, and P. M. Midgley. Cambridge (United Kingdom): Cambridge University Press.

Jablonka E., Lamb M. J. 2005. Evolution in Four Dimensions: Genetic, Epigenetic, Behavioral, and Symbolic Variation in the History of Life. Cambridge (Massachusetts): MIT Press.

Jablonka E., Lamb M. J. 2007. Précis of Evolution in Four Dimensions. Behavioral and Brain Sciences 30:353-392.

Jackson D. C., Schmidt-Nielsen K. 1964. Countercurrent heat exchange in the respiratory passages. Proceedings of the National Academy of Sciences of the United States of America 51:1192-1197.

Jackson T. P., Bennett N. C., Spinks A. C. 2004. Is the distribution of the arid-occuring otomyine rodents of southern Africa related to physiological adaptation or refuge type? Iournal of Zoology 264:1-10.

Lande R., Shannon S. 1996. The role of genetic variation in adaptation and population persistence in a changing environment. Evolution 50:434-437.

Larson G., Stephens P. A., Tehrani J. J., Layton R. H. 2013. Exapting exaptation. Trends in Ecology and Evolution 28:497-498.

Ledón-Rettig C. C., Pfennig D. W., Nascone-Yoder N. 2008. Ancestral variation and the potential for genetic accommodation in larval amphibians: implications for the evolution of novel feeding strategies. Evolution and Development 10:316-325.
Lewontin R. C. 1970. The units of selection. Annual Review of Ecology and Systematics 1:1-18.

Li Y., Ye W., Wang M., Yan X. 2009. Climate change and drought: a risk assessment of crop-yield impacts. Climate Research 39:31-46.

Lind M. I., Yarlett K., Reger J., Carter M. J., Beckerman A. P. 2015. The alignment between phenotypic plasticity, the major axis of genetic variation and the response to selection. Proceedings of the Roval Society B: Biological Sciences 282:20151651.

Maickel R. P., Stern D. N., Takabatake E., Brodie B. B. 1967. The sympathetic nervous system as a homeostatic mechanism. II. Effect of adrenocortical hormones on body temperature maintenance of cold-exposed adrenalectomized rats. Journal of Pharmacology and Experimental Therapeutics 157: 111-116.

McCue M. D. 2010. Starvation physiology: reviewing the different strategies animals use to survive a common challenge. Comparative Biochemistry and Physiology Part A: Molecular and Integrative Physiology 156:1-18.

McEwen B. S., Wingfield J. C. 2003. The concept of allostasis in biology and biomedicine. Hormones and Behavior 43:2-15.

McNaughton S. J., Wallace L. L., Coughenour M. B. 1983. Plant adaptation in an ecosystem context: effects of defoliation, nitrogen, and water on growth of an African C4 sedge. Ecology 64:307-318.

Meigs P. 1953. World distribution of arid and semiarid homoclimates. Pages 203-209 in Reviews of Research on Arid Zone Hydrology. Arid Zone Research Series, Volume 1. Paris (France): UNESCO.

Mery F., Burns J. G. 2010. Behavioural plasticity: an interaction between evolution and experience. Evolutionary Ecology 24:571-583.

Michel M. J., Chevin L.-M., Knouft J. H. 2014. Evolution of phenotype-environment associations by genetic responses to selection and phenotypic plasticity in a temporally autocorrelated environment. Evolution 68:1374-1384.

Miller G. H., Fogel M. L., Magee J. W., Gagan M. K., Clarke S. J., Johnson B. J. 2005. Ecosystem collapse in Pleistocene Australia and a human role in megafaunal extinction. Science 309:287-290.

Mitchell D., Laburn H. P., Nijland M. J. M., Zurovsky Y., Mitchell G. 1987. Selective brain cooling and survival. South African Journal of Science 83:598-604.

Mitchell D., Maloney S. K., Jessen C., Laburn H. P., Kamerman P. R., Mitchell G., Fuller A. 2002. Adaptive heterothermy and selective brain cooling in arid-zone mammals. Comparative Biochemistry and Physiology Part B: Biochemistry and Molecular Biology 131:571-585.

Moritz C., Agudo R. 2013. The future of species under climate change: resilience or decline? Science 341:504-508. 
Murren C. J., Auld J. R., Callahan H., Ghalambor C. K., Handelsman C. A., Heskel M. A., Kingsolver J. G., Maclean H. J., Masel J., Maughan H., Pfennig D. W., Reylea R. A., Seiter S., Snell-Rood E., Steiner U. K., Schlichting C. D. 2015. Constraints on the evolution of phenotypic plasticity: limits and costs of phenotype and plasticity. Heredity 115:293-301.

Nash D. J., Engineering Group Working Party. 2012. Desert environments. Geological Society, London, Engineering Geology Special Publications 25:7-32.

Negus N. C., Berger P. J., Brown B. W. 1986. Microtine population dynamics in a predictable environment. Canadian Journal of Zoology 64:785-792.

Nettle D., Bateson M. 2015. Adaptive developmental plasticity: what is it, how can we recognize it and when can it evolve? Proceedings of the Roval Society B: Biological Sciences 282:20151005.

Ockendon N., Baker D. J., Carr J. A., White E. C., Almond R. E. A., Amano T., Bertram E., Bradbury R. B., Bradley C., Butchart S. H. M., Doswald N., Foden W., Gill D. J. C., Green R. E., Sutherland W. J., Tanner E. V. J., Pearce-Higgins J. W. 2014. Mechanisms underpinning climatic impacts on natural populations: altered species interactions are more important than direct effects. Global Change Biology 20:2221-2229.

Oppenheimer M., Campos M., Warren R., Birkmann J., Luber G., O’Neill B., Takahashi K. 2014. Emergent risks and key vulnerabilities. Pages 1039-1099 in Climate Change 2014: Impacts, Adaptation, and Vulnerability: Part A: Global and Sectoral Aspects: Contribution of Working Group II to the Fifth Assessment Report of the Intergovernmental Panel on Climate Change. Cambridge (United Kingdom): Cambridge University Press.

Ostrowski S., Williams J. B., Mésochina P., Sauerwein H. 2006. Physiological acclimation of a desert antelope, Arabian oryx (Oryx leucoryx), to long-term food and water restriction. Iournal of Comparative Physiology B: Biochemical. Systems, and Environmental Physiology 176:191-201.

Ouajd S., Kamel B. 2009. Physiological particularities of dromedary (Camelus dromedarius) and experimental implications. Scandinavian Journal of Laboratory Animal Science 36:19-29.

Ozgul A., Tuljapurkar S., Benton T. G., Pemberton J. M., Clutton-Brock T. H., Coulson T. 2009. The dynamics of phenotypic change and the shrinking sheep of St. Kilda. Science 325:464-467.

Ozgul A., Childs D. Z., Oli M. K., Armitage K. B., Blumstein D. T., Olson L. E., Tuljapurkar S., Coulson T. 2010. Coupled dynamics of body mass and population growth in response to environmental change. Nature 466:482-485.

Pekár S., Michalko R., Korenko S., Šedo O., Líznarová E., Sentenská L., Zdráhal Z. 2013. Phenotypic integration in a series of trophic traits: tracing the evolution of myrmecophagy in spiders (Araneae). Zoology 116:27-35.

Pianka E. R. 2011. Evolutionary Ecology. Seventh Edition. Austin (Texas): E. R. Pianka.

Piersma T., Drent J. 2003. Phenotypic flexibility and the evolution of organismal design. Trends in Ecology and Evolution 18:228-233.

Piersma T., Lindström Å. 1997. Rapid reversible changes in organ size as a component of adaptive behaviour. Trends in Ecology and Evolution 12:134-138.

Piersma T., van Gils J. A. 2010. The Flexible Phenotype: A Body-Centred Integration of Ecology, Physiology, and Behaviour. Oxford (United Kingdom): Oxford University Press.

Pimm S. L. 2009. Climate disruption and biodiversity. Current Biology 19:R595-R601.

Pinter A. J. 1994. Climatic factors, reproductive success and population dynamics in the montane vole, Microtus montanus. University of Wyoming $\mathrm{Na}$ tional Park Service Research Center Annual Report 18:92-93.

Podos J., Southall J. A., Rossi-Santos M. R. 2004. Vocal mechanics in Darwin's finches: correlation of beak gape and song frequency. Lournal of Experimental Biology 207:607-619.

Quintero I., Wiens J. J. 2013. Rates of projected climate change dramatically exceed past rates of climatic niche evolution among vertebrate species. Ecology Letters 16:1095-1103.

Randall J. A. 1993. Behavioural adaptations of desert rodents (Heteromyidae). Animal Behaviour 45: 263-287.

Reik W. 2007. Stability and flexibility of epigenetic gene regulation in mammalian development. $\underline{\mathrm{Na}}$ ture 447:425-432.

Rezende E. L., Diniz-Filho J. A. F. 2012. Phylogenetic analyses: comparing species to infer adaptations and physiological mechanisms. Comphrensive Physiology 2:639-674.

Rivers J. W., Liebl A. L., Owen J. C., Martin L. B., Betts M. G. 2012. Baseline corticosterone is positively related to juvenile survival in a migrant passerine bird. Functional Ecology 26:1127-1134.

Robertson B. A., Rehage J. S., Sih A. 2013. Ecological novelty and the emergence of evolutionary traps. Trends in Ecology and Evolution 28:552-560.

Romero L. M. 2012. Using the reactive scope model to understand why stress physiology predicts survival during starvation in Galápagos marine iguanas. General and Comparative Endocrinology 176:296-299.

Romero L. M., Dickens M. J., Cyr N. E. 2009. The reactive scope model-a new model integrating homeostasis, allostasis, and stress. Hormones and Behavior 55:375-389.

Rymer T. L., Pillay N., Schradin C. 2013. Extinction or survival? Behavioral flexibility in response to 
environmental change in the African striped mouse Rhabdomys. Sustainability 5:163-186.

Saccheri I. J., Rousset F., Watts P. C., Brakefield P. M., Cook L. M. 2008. Selection and gene flow on a diminishing cline of melanic peppered moths. Proceedings of the National Academy of Sciences of the United States of America 105:16212-16217.

Sarma V. V. L. N., Krishna G. M., Malini B. H., Rao K. N. 2001. Landuse/landcover change detection through remote sensing and its climatic implications in the Godavari delta region. Iournal of the Indian Society of Remote Sensing 29:85-91.

Scheiner S. M., Gomulkiewicz R., Holt R. D. 2015. The genetics of phenotypic plasticity. XIV. Coevolution. American Naturalist 185:594-609.

Schradin C., Pillay N. 2005. Demography of the striped mouse (Rhabdomys pumilio) in the succulent karoo. Mammalian Biology 70:84-92.

Schradin C., Krackow S., Schubert M., Keller C., Schradin B., Pillay N. 2007. Regulation of activity in desert-living striped mice: the importance of basking. Ethology 113:606-614.

Seager R., Tang M., Held I., Kushnir Y., Lu J., Vecchi G., Huang H.-P., Harnik N., Leetmaa A., Lau N.-C., Li C., Velez J., Naik N. 2007. Model projections of an imminent transition to a more arid climate in southwestern North America. Science 316: 1181-1184.

Siebert B. D., Macfarlane W. V. 1975. Dehydration in desert cattle and camels. Physiological Zoology 48:36-48.

Sih A., Ferrari M. C. O., Harris D. J. 2011. Evolution and behavioural responses to human-induced rapid environmental change. Evolutionary Applications 4:367-387.

Smit B., Burton I., Klein R. J. T., Wandel J. 2000. An anatomy of adaptation to climate change and variability. Climate Change 45:223-251.

Sperry J. H., Weatherhead P. J. 2008. Prey-mediated effects of drought on condition and survival of a terrestrial snake. Ecology 89:2770-2776.

Standen E. M., Du T. Y., Larsson H. C. E. 2014. Developmental plasticity and the origin of tetrapods. Nature 513:54-58.

Steiner U. K., Van Buskirk J. 2008. Environmental stress and the costs of whole-organism phenotypic plasticity in tadpoles. Journal of Evolutionary Biology 21:97-103.

Stewart D. R. M. 1963. The Arabian oryx (Oryx leucoryx Pallas). African Journal of Ecology 1:103-117.

Tanentzap A. J., Lee W. G., Schulz K. A. C. 2013. Niches drive peaked and positive relationships between diversity and disturbance in natural ecosystems. Ecosphere 4:133.

Taylor C. R. 1970. Dehydration and heat: effects on temperature regulation of East African ungulates. American Journal of Physiology 219:1136-1139.
Valladares F., Balaguer L., Martinez-Ferri E., PerezCorona E., Manrique E. 2002. Plasticity, instability and canalization: is the phenotypic variation in seedlings of sclerophyll oaks consistent with the environmental unpredictability of Mediterranean ecosystems? New Phytologist 156:457-467.

Van Buskirk J., Steiner U. K. 2009. The fitness costs of developmental canalization and plasticity. Iournal of Evolutionary Biology 22:852-860.

Vicente-Serrano S. M., Gouveia C., Camarero J.J., Beguería S., Trigo R., López-MorenoJ. I., Azorín-Molina C., Pasho E., Lorenzo-Lacruz J., Revuelto J., Morán-Tejeda E., Sanchez-Lorenzo A. 2013. Responses of vegetation to drought time-scales across global land biomes. Proceedings of the National Academv of Sciences of the United States of America 110: 52-57.

Viles H. A., Goudie A. S. 2013. Weathering in the central Namib Desert, Namibia: controls, processes and implications. Journal of Arid Environments 93:20-29.

Walker B. H., Emslie R. H., Owen-Smith R. N., Scholes R. J. 1987. To cull or not to cull: lessons from a southern African drought. Journal of Applied Ecology 24:381-401.

Ward D. 2009. Morphological, physiological, and behavioural adaptations of desert animals to the abiotic environment. Pages 66-101 in The Biology of Deserts, by D. Ward. Oxford (United Kingdom): Oxford University Press.

Webb J. K., Letnic M., Jessop T. S., Dempster T. 2014. Behavioural flexibility allows an invasive vertebrate to survive in a semi-arid environment. Biology Letters 10:20131014.

West-Eberhard M. J. 1989. Phenotypic plasticity and the origins of diversity. Annual Review of Ecology and Systematics 20:249-278.

Williams J. B., Ostrowski S., Bedin E., Ismail K. 2001. Seasonal variation in energy expenditure, water flux and food consumption of Arabian oryx Oryx leucoryx. Iournal of Experimental Biology 204:23012311.

Williams S. E., Shoo L. P., Isaac J. L., Hoffmann A. A., Langham G. 2008. Towards an integrated framework for assessing the vulnerability of species to climate change. PLOS Biology 6:e325.

Willmer P., Stone G., Johnson I. 2000. Environmental Physiology of Animals. Malden (Massachusetts): Blackwell Science.

Wingfield J. C. 2013. The comparative biology of environmental stress: behavioural endocrinology and variation in ability to cope with novel, changing environments. Animal Behaviour 85: 1127-1133.

Ylönen H., Ronkainen H. 1994. Breeding suppression in the bank vole as antipredatory adaptation in a predictable environment. Evolutionary Ecology 8:658-666. 
Yousef M. K., Johnson H. D. 1975. Thyroid activity in desert rodents: a mechanism for lowered metabolic rate. American Journal of Physiology 229:427-431.

Zhang Y. M., Chen Y. N., Pan B. R. 2005. Distribution and floristics of desert plant communities in the lower reaches of Tarim River, southern Xinjiang, People's Republic of China. Journal of Arid Environments 63:772-784.
Zhang Z.-Q., Wang D.-H. 2007. Seasonal changes in thermogenesis and body mass in wild Mongolian gerbils (Meriones unguiculatus). Comparative Biochemistrv and Physiology Part A: Molecular and Integrative Physiology 148:346-353.

Associate Editor: Andrew Sih Handling Editor: John J. Wiens

\section{APPENDIX 1}

\section{References associated with Tables 1, 2a, 2b, and $2 c$}

Alagaili A. N., Mohammed O. B., Bennett N. C., Oosthuizen M. K. 2013. A tale of two jirds: the locomotory activity patterns of the King jird (Meriones rex) and Lybian jird (Meriones lybicus) from Saudi Arabia. Journal of Arid Environments 88:102-112.

Albert S. K., Krausman P. R. 1993. Desert mule deer and forage resources in Southwest Arizona. Southwestern Naturalist 38:198-205.

Aulagnier S., Granjon L., Shenbrot G., Bukhnikashvili A. 2008. Meriones libycus. IUCN 2014. IUCN Red List of Threatened Species, Version 2014.3. http://www.iucnredlist.org. (Accessed 3 December 2014).

Bartholomew G. A., MacMillen R. E. 1961. Oxygen consumption, estivation, and hibernation in the kangaroo mouse, Microdipodops pallidus. Physiological Zoology 34:177-183.

Baudinette R. V., Snyder G. K., Frappell P. B. 1992. Energetic cost of locomotion in the Tammar wallaby. American Journal of Physiology: Regulatory, Integrative and Comparative Physiology 262:R771-R778.

Baumgardner G. D. 1991. Dipodomys compactus. Mammalian Species 369:1-4.

Ben Goumi M., Riad F., Giry J., de la Farge F., Safwate A., Davicco M.-J., Barlet J.-P. 1993. Hormonal control of water and sodium in plasma and urine of camels during dehydration and rehydration. General and Comparative Endocrinology 89:378-386.

Bennett A. F., Huey R. B., John-Alder H., Nagy K. A. 1984. The parasol tail and thermoregulatory behavior of the Cape ground squirrel Xerus inauris. Physiological Zoology 57:57-62.

Bothma J. du P., Riche E. A. N. le. 1984. Aspects of the ecology and the behaviour of the leopard Panthera pardus in the Kalahari desert. Koedoe Supplement (1984):259-279.

Bozinovic F., Contreras L. C. 1990. Basal rate of metabolism and temperature regulation of two desert herbivorous octodontid rodents: Octomys mimax and Tympanoctomys barrerae. Oecologia 84:567-570.

Bozinovic F., Gallardo P. A., Visser G. H., Cortés A. 2003. Seasonal acclimatization in water flux rate, urine osmolality and kidney water channels in free-living degus: molecular mechanisms, physiological processes and ecological implications. Journal of Experimental Biology 206:2959-2966.

Bradford D. F. 1974. Water stress of free-living Peromyscus truei. Ecology 55:1407-1414.

Brown J. H., Munger J. C. 1985. Experimental manipulation of a desert rodent community: food addition and species removal. Ecology 66:1545-1563.

Buffenstein R. 1984. Energy and water balance during torpor and hydropenia in the pigmy gerbil, Gerbillus pusillus. Journal of Comparative Physiology B: Biochemical, Systems, and Environmental Physiology 154:535-544.

Buffenstein R. 1985. The effect of a high fibre diet on energy and water balance in two Namib desert rodents. Journal of Comparative Physiology B: Biochemical, Systems, and Environmental Physiology 155:211-218.

Buffenstein R., Campbell W. E., Jarvis J. U. M. 1985. Identification of crystalline allantoin in the urine of African Cricetidae (Rodentia) and its role in their water economy. Journal of Comparative Physiology B: Biochemical, Systems, and Environmental Physiology 155:493-499.

Bukovetzky E., Fares F., Schwimmer H., Haim A. 2012. Reproductive and metabolic responses of desert adapted common spiny male mice (Acomys cahirinus) to vasopressin treatment. Comparative Biochemistry and Physiology Part A: Molecular and Integrative Physiology 162:349-356.

Cain J. W. III, Krausman P. R., Rosenstock S. S., Turner J. C. 2006. Mechanisms of thermoregulation and water balance in desert ungulates. Wildlife Society Bulletin 34:570-581.

Carpenter R. E. 1966. A comparison of thermoregulation and water metabolism in the kangaroo rats Dipodomys agilis and Dipodomys merriami. University of California Publications in Zoology 78:1-36.

Carpenter R. E., Graham J. B. 1967. Physiological responses to temperature in the long-nosed bat, Leptonycteris sanborni. Comparative Biochemistry and Physiology 22:709-722. 
Casey N. H., van Niekerk W. A. 1988. The Boer goat. I. Origin, adaptability, performance testing, reproduction and milk production. Small Ruminant Research 1:291-302.

Castel M., Abraham M. 1972. Effects of a dry diet on the antidiuretic hormone content of the neurohypophysis in spiny mice as compared to the albino rat and mouse. General and Comparative Endocrinology 19:48-55.

Chappell M. A., Bartholomew G. A. 1981a. Activity and thermoregulation of the antelope ground squirrel Ammospermophilus leucurus in winter and summer. Physiological Zoology 54:215-223.

Chappell M. A., Bartholomew G. A. 1981b. Standard operative temperatures and thermal energetics of the antelope ground squirrel Ammospermophilus leucurus. Physiological Zoology 54:81-93.

Chen X., Dickman C. R., Thompson M. B. 1998. Diet of the mulgara, Dasycercus cristicauda (Marsupialia: Dasyuridae), in the Simpson Desert, central Australia. Wildlife Research 25:233-242.

Christian D. P. 1978. Effects of humidity and body size on evaporative water loss in three desert rodents. Comparative Biochemistry and Physiology Part A: Physiology 60:425-430.

Christian D. P. 1980. Vegetative cover, water resources, and microdistributional patterns in a desert rodent community. Journal of Animal Ecology 49:807-816.

Cornelius C. E., Kaneko J. J. 1962. Erythrocyte life span in the guanaco. Science 137:673-674.

Curtis B. A., Perrin M. R. 1979. Food preference of the vlei rat (Otomys irroratus) and the four-striped mouse (Rhabdomys pumilio). South African Journal of Zoology 14:224-229.

Cypher B. L. 2003. Foxes (Vulpes species, Urocyon species, and Alopex lagopus). Pages 511-546 in Wild Mammals of North America: Biology, Management, and Conservation, edited by G. A. Feldhamer, B. C. Thompson, and J. A. Chapman. Second Edition. Baltimore (Maryland): Johns Hopkins University Press.

Daly M., Daly S. 1973. On the feeding ecology of Psammomys obesus (Rodentia: Gerbillinae) in Wadi Saoura, Algeria. Mammalia 37:545-561.

Dawson T. J., Brown G. D. 1970. A comparison of the insulative and reflective properties of the fur of desert kangaroos. Comparative Biochemistry and Physiology 37:23-38.

Dawson T. J., Taylor C. R. 1973. Energetic cost of locomotion in kangaroos. Nature 246:313-314.

Dawson T. J., Denny M. J. S., Russell E. M., Ellis B. 1975. Water usage and diet preferences of free ranging kangaroos, sheep and feral goats in the Australian arid zone during summer. Journal of $\mathrm{Zo}^{-}$ ology 177:1-23.

de Rouffignac C., Morel F. 1965. Etude comparée du renouvellement de l'eau chez quatre espèces de rongeurs, dont deux espèces d'habitat désertique. Journal of Physiology 58:309-322.

Deblinger R. D., Alldredge A. W. 1989. Management implications of variations in pronghorn social behavior. Wildlife Society Bulletin 17:82-87.

Degen A. A. 1977. Fat-tailed Awassi and German mutton merino sheep under semi-arid conditions. 1. Total body water, its distribution and water turnover. Journal of Agricultural Science 88:693-698.

Degen A. A., Shkolnik A. 1978. Thermoregulation in fat-tailed Awassi, a desert sheep, and in German mutton merino, a mesic sheep. Physiological Zoology 51:333-339.

Dereje M., Udén P. 2005. The browsing dromedary camel. I. Behaviour, plant preference and quality of forage selected. Animal Feed Science and Technology 121:297-308.

Dexter N. 2003. The influence of pasture distribution, and temperature on adult body weight of feral pigs in a semi-arid environment. Wildlife Research 30:75-79.

Diaz G. B., Ojeda R. A. 1999. Kidney structure and allometry of Argentine desert rodents. Journal of Arid Environments 41:453-461.

Donadio E., Buskirk S. W., Novaro A. J. 2012. Juvenile and adult mortality patterns in a vicuña (Vicugna vicugna) population. Journal of Mammalogy 93:1536-1544.

Downs C. T., Perrin M. R. 1990. The effect of diet on water and energy turnover rates of four Gerbillurus species in captivity. Journal of Zoology 222:215-233.

Downs C. T., Perrin M. R. 1991. Urinary concentrating ability of four Gerbillurus species of southern Africa arid regions. Journal of Arid Environments 20:71-81.

Downs C. T., Perrin M. R. 1994. Comparative aspects of the thermal biology of the short-tailed gerbil, Desmodillus auricularis, and the bushveld gerbil, Tatera leucogaster. Journal of Thermal Biology 19:385-392.

du Plessis A., Kerley G. I. H., deo Winter P. E. 1992. Refuge microclimates of rodents: a surface nesting Otomys unisulcatus and a burrowing Parotomys brantsii. Acta Theriologica 37:351-358.

Ehrhardt N., Heldmaier G., Exner C. 2005. Adaptive mechanisms during food restriction in Acomys russatus: the use of torpor for desert survival. Journal of Comparative Physiology B: Biochemical, Systems, and Environmental Physiology 175:193-200.

El-Hadi H. M. 1986. The effect of dehydration on Sudanese desert sheep and goats. Journal of Agricultural Science 106:17-20.

El Hilali M., Veillat J.-P. 1975. Jaculus orientalis: a true hibernator. Mammalia 39:401-404.

El Ouezzani S., Lafon P., Tramu G., Magoul R. 2001. Neuropeptide Y gene expression in the jerboa arcuate nucleus: modulation by food deprivation and relationship with hibernation. Neuroscience Letters 305:127-130. 
Elkhawad A. O. 1992. Selective brain cooling in desert animals: the camel (Camelus dromedarius). Comparative Biochemistry and Physiology Part A: Physiology 101:195-201.

Emmanuel B., Howard B. R., Emady M. 1976. Urea degradation in the camel. Canadian Journal of Animal Science 56:595-601.

Faye B. 1997. Le guide de l'élevage du dromadaire. Libourne (France): Sanofi Santé Nutrition Animale.

Fielden L. J., Perrin M. R., Hickman G. C. 1990. Water metabolism in the Namib Desert golden mole, Eremitalpa granti namibensis (Chrysochloridae). Comparative Biochemistry and Physiology Part A: Physiology 96:227-234.

Finberg J. P., Yagil R., Berlyne G. M. 1978. Response of the renin-aldosterone system in the camel to acute dehydration. Journal of Applied Physiology 44:926-930.

Fourie F. le R., Haim A. 1980. Enzymatic activity of rodents acclimated to cold and long scotophase. International Journal of Biometeorology 24:237-241.

Frean J. L., Downs C. T., Lovegrove B. G. 1998. Osmoregulatory capacity of an arboreal rodent Thallomys nigricauda. Journal of Arid Environments 40:97-107.

Fuller A., Maloney S. K., Mitchell G., Mitchell D. 2004. The eland and the oryx revisited: body and brain temperatures of free-living animals. International Congress Series 1275:275-282.

Fuller A., Kamerman P. R., Maloney S. K., Matthee A., Mitchell G., Mitchell D. 2005. A year in the thermal life of a free-ranging herd of springbok Antidorcas marsupialis. Journal of Experimental Biology 208:2855-2864.

Funston P. J., Skinner J. D., Dott H. M. 1994. Seasonal variation in movement patterns, home range and habitat selection of buffaloes in a semi-arid habitat. African Journal of Ecology 32:100-114.

Geiser F. 2010. Aestivation in mammals and birds. Pages 95-111 in Aestivation: Molecular and Physiological Aspects, edited by C. A. Navas and J. E. Carvalho. Berlin (Germany): Springer.

Geiser F., Pavey C. R. 2007. Basking and torpor in a rock-dwelling desert marsupial: survival strategies in a resource-poor environment. Journal of Comparative Physiology B: Biochemical, Systems, and Environmental Physiology 177:885-892.

Ghobrial L. I. 1970. The water relations of the desert antelope Gazella dorcas dorcas. Physiological Zoology 43:249-256.

Giannoni S. M., Dacar M., Taraborelli P., Borghi C. E. 2001. Seed hoarding by rodents of the Monte Desert, Argentina. Austral Ecology 26:259-263.

Giannoni S. M., Borghi C. E., Dacar M., Campos C. M. 2005. Main food categories in diets of sigmodontine rodents in the Monte (Argentina). Mastozoología Neotropical 12:181-187.

Gihad El S. A., El Gallad T. T., Sooud A. E. O., Abou El Nasr H. M., Farid M. F. A. 1989. Feed and water intake, digestibility and nitrogen utilization by camels compared to sheep and goats fed low protein desert by-products. Options MéditerranéennesSérie Séminaires 2:75-81.

Gilad O., Grant W. E., Saltz D. 2008. Simulated dynamics of Arabian oryx (Oryx leucoryx) in the Israeli Negev: effects of migration corridors and post-reintroduction changes in natality on population viability. Ecological Modelling 210:169-178.

Golightly R. T. Jr., Ohmart R. D. 1983. Metabolism and body temperature of two desert canids: coyotes and kit foxes. Journal of Mammalogy 64:624-635.

Grigg G., Beard L., Dörges B., Heucke J., Coventry J., Coppock A., Blomberg S. 2009. Strategic (adaptive) hypothermia in bull dromedary camels during rut; could it increase reproductive success? Biology Letters 5:853-856.

Grubbs D. E. 1980. Tritiated water turnover in freeliving desert rodents. Comparative Biochemistry and Physiology Part A: Physiology 66:89-98.

Gutman R., Choshniak I., Kronfeld-Schor N. 2006. Defending body mass during food restriction in Acomys russatus: a desert rodent that does not store food. American Journal of Physiology: Regulatory, Integrative and Comparative Physiology 290:R881-R891.

Gutman R., Hacmon-Keren R., Choshniak I., KronfeldSchor N. 2008. Effect of food availability and leptin on the physiology and hypothalamic gene expression of the golden spiny mouse: a desert rodent that does not hoard food. American Journal of Physiology: Regulatory, Integrative and Comparative Physiology 295:R2015-R2023.

Haim A. 1984. Adaptive variations in heat production within gerbils (genus Gerbillus) from different habitats. Oecologia 61:49-52.

Haim A., Borut A. 1981. Heat production and dissipation in golden spiny mice, Acomys russatus from two extreme habitats. Journal of Comparative Physiology B: Biochemical, Systems, and Environmental Physiology 142:445-450.

Haim A., Fairall N. 1986. Geographical variations in heat production and dissipation within two populations of Rhabdomys pumilio (Muridae). Comparative Biochemistry and Physiology Part A: Physiology 84:111-112.

Haim A., Fourie F. le R. 1980a. Heat production in nocturnal (Praomys natalensis) and diurnal (Rhabdomys pumilio) South African murids. South African Journal of Zoology 15:91-94.

Haim A., Fourie F. le R. 1980b. Heat production in cold and long scotophase acclimated and winter acclimatized rodents. International Journal of Biometeorology 24:231-236.

Haim A., Izhaki I. 1993. The ecological significance of resting metabolic rate and non-shivering thermogenesis for rodents. Journal of Thermal Biology 18:71-81. 
Haim A., Rozenfeld F. M. 1995. Temporal segregation in co-existing Acomys species: the possible role of nest site. Journal of Arid Environments 29:505-509.

Haim A., Heth G., Avnon Z., Nevo E. 1984. Adaptive physiological variation in nonshivering thermogenesis and its significance in speciation. Journal of Comparative Physiology B: Biochemical, Systems, and Environmental Physiology 154:145-147.

Haim A., Pelaot I., Sela A. 1986. Comparison of ecophysiological parameters between two Apodemus species coexisting in the same habitat. Pages 33-40 in Environmental Quality and Ecosystem Stability, Volume III A/B, edited by Z. Dubinsky and Y. Steinberger. Ramat-Gan (Israel): Bar-Ilan University Press.

Haines H., Macfarlane W. V., Setchell C., Howard B. 1974. Water turnover and pulmocutaneous evaporation of Australian desert dasyurids and murids. American Journal of Physiology 227:958-963.

Hansen M. C. 1982. Desert bighorn sheep: another view. Wildlife Society Bulletin 10:133-140.

Hartman L. A., Morton M. L. 1973. Plasma volume changes in ground squirrels during water deprivation. Comparative Biochemistry and Physiology Part A: Physiology 46:79-94.

Hatough-Bouran A. 1990. The burrowing habits of desertic rodents Jaculus jaculus and Gerbillus dasyurus in the Shaumari Reserve in Jordan. Mammalia 54:341-359.

Heimeier R. A., Donald J. A. 2006. The response of the natriuretic peptide system to water deprivation in the desert rodent, Notomys alexis. Comparative Biochemistry and Physiology Part A: Molecular and Integrative Physiology 143:193-201.

Hetem R. S., Strauss W. M., Fick L. G., Maloney S. K., Meyer L. C. R., Shobrak M., Fuller A., Mitchell D. 2010. Variation in the daily rhythm of body temperature of free-living Arabian oryx (Oryx leuco$r y x)$ : does water limitation drive heterothermy? Journal of Comparative Physiology B: Biochemical, Systems, and Environmental Physiology 180:1111-1119.

Hetem R. S., Strauss W. M., Heusinkveld B. G., de Bie S., Prins H. H. T., van Wieren S. E. 2011. Energy advantages of orientation to solar radiation in three African ruminants. Journal of Thermal Biology 36:452-460.

Hetem R. S., Strauss W. M., Fick L. G., Maloney S. K., Meyer L. C. R., Fuller A., Shobrak M., Mitchell D. 2012. Selective brain cooling in Arabian oryx (Oryx leucoryx): a physiological mechanism for coping with aridity? Journal of Experimental Biology 215:3917-3924.

Hinds D. S., MacMillen R. E. 1985. Scaling of energy metabolism and evaporative water loss in heteromyid rodents. Physiological Zoology 58:282-298.

Hinton H. E., Dunn A. M. S. 1967. Mongooses: Their Natural History and Behaviour. Edinburgh (United Kingdom): Oliver \& Boyd.
Hochman V., Kotler B. P. 2006. Effects of food quality, diet preference and water on patch use by Nubian ibex. Oikos 112:547-554.

Hoppe P. P. 1977. Comparison of voluntary food and water consumption and digestion in Kirk's dikdik and suni. African Journal of Ecology 15:41-48.

Howell A. B., Gersh I. 1935. Conservation of water by the rodent Dipodomys. Journal of Mammalogy 16:1-9.

Hudson J. W. 1964. Temperature regulation in the round-tailed ground squirrel, Citellus tereticaudus. Annales Academiae Scientiarum Fennicae, Series A IV 71:217-233.

Hulbert A. J., Dawson T. J. 1974. Thermoregulation in perameloid marsupials from different environments. Comparative Biochemistry and Physiology Part A: Physiology 47:591-616.

Hulbert A. J., Hinds D. S., MacMillen R. E. 1985. Minimal metabolism, summit metabolism and plasma thyroxine in rodents from different environments. Comparative Biochemistry and Physiology Part A: Physiology 81:687-693.

Hume J. D., Rübsamen K., Engelhardt W. V. 1980. Nitrogen metabolism and urea kinetics in the rock hyrax (Procavia habessinica). Journal of Comparative Physiology B: Biochemical, Systems, and Environmental Physiology 138:307-314.

Ilan M., Yom-Tov Y. 1990. Diel activity pattern of a diurnal desert rodent, Psammomys obesus. Journal of Mammalogy 71:66-69.

Intress C., Best T. L. 1990. Dipodomys panamintinus. Mammalian Species 354:1-7.

Jaber L. S., Habre A., Rawda N., Abi Said M., Barbour E. K., Hamadeh S. 2004. The effect of water restriction on certain physiological parameters in Awassi sheep. Small Ruminant Research 54:115-120.

Jaber L. S., Hanna N., Barbour E. K., Abi Said M., Rawda N., Chedid M., Hamadeh S. K. 2011. Fat mobilization in water restricted Awassi ewes supplemented with vitamin C. Journal of Arid Environments 75:625-628.

Jackson D. C., Schmidt-Nielsen K. 1964. Countercurrent heat exchange in the respiratory passages. Proceedings of the National Academy of Sciences of the United States of America 51:1192-1197.

Jackson T. P., Bennett N. C., Spinks A. C. 2004. Is the distribution of the arid-occurring otomyine rodents of southern Africa related to physiological adaptation or refuge type? Journal of Zoology 264:1-10.

Kaißling B., de Rouffignac C., Barrett J. M., Kriz W. 1975. The structural organization of the kidney of the desert rodent Psammomys obesus. Anatomy and Embryology 148:121-143.

Kam M., Degen A. A. 1993. Effect of dietary preformed water on energy and water budgets of two sympatric desert rodents, Acomys russatus and Acomys cahirinus. Journal of Zoology 231:51-59. 
Kamau J. M. Z., Maina J. N., Maloiy G. M. O. 1984. The design and the role of the nasal passages in temperature regulation in the dik-dik antelope (Rhynchotragus kirki) with observations on the carotid rete. Respiration Physiology 56:183-194.

Kataria N., Kataria A. K. 2006. Endocrine and metabolic responses of Marwari sheep in arid tract. Slovenian Veterinary Research 43:135-142.

Kennedy P. M., Hume I. D. 1978. Recycling of urea nitrogen to the gut of the tammar wallaby (Macropus eugenii). Comparative Biochemistry and Physiology Part A: Physiology 61:117-121.

Khachadurian A. K., Adrouni B., Yacoubian H. 1966. Metabolism of adipose tissue in the fat tail of the sheep in vivo. Journal of Lipid Research 7:427-436.

Khalil F., Tawfic J. 1963. Some observations on the kidney of the desert J. jaculus and G. gerbillus and their possible bearing on the water economy of these animals. Journal of Experimental Zoology Part A 154:259-271.

Khan M. S., Ghosh P. K., Sasidharan T. O. 1978. Effect of acute water restriction on plasma proteins and on blood and urinary electrolytes in Barmer goats of the Rajasthan desert. Journal of Agricultural Science 91:395-398.

King J. M., Kingaby G. P., Colvin J. G., Heath B. R. 1975. Seasonal variation in water turnover by oryx and eland on the Galana Game Ranch Research Project. African Journal of Ecology 13:287-296.

Kinnear J. E., Purohit K. G., Main A. R. 1968. The ability of the tammar wallaby (Macropus eugenii, Marsupialia) to drink sea water. Comparative Biochemistry and Physiology 25:761-782.

Koford C. B. 1968. Peruvian desert mice: water independence, competition, and breeding cycle near the equator. Science 160:552-553.

Kronfeld-Schor N., Haim A., Dayan T., Zisapel N., Klingenspor M., Heldmaier G. 2000. Seasonal thermogenic acclimation of diurnally and nocturnally active desert spiny mice. Physiological and Biochemical Zoology 73:37-44.

Krysl L. J., Sowell B. F., Hubbert M. E., Plumb G. E., Jewett T. K., Smith M. A., Waggoner J. W. 1984. Horses and cattle grazing in the Wyoming red desert. II. Dietary quality. Journal of Range Management 37:252-255.

Laden S., Nehmadi L., Yagil R. 1987. Dehydration tolerance in Awassi fat-tailed sheep. Canadian Journal of Zoology 65:363-367.

Lagos V. O., Bozinovic F., Contreras L. C. 1995. Microhabitat use by a small diurnal rodent (Octodon degus) in a semiarid environment: thermoregulatory constraints or predation risk? Journal of Mammalogy 76:900-905.

Langman V. A., Maloiy G. M. O., Schmidt-Nielsen K., Schroter R. C. 1979. Nasal heat exchange in the giraffe and other large mammals. Respiration Physiology 37:325-333.
Larcombe A. N., Withers P. C. 2006. Thermoregulatory, metabolic and ventilatory physiology of the western barred bandicoot (Perameles bougainville bougainville) in summer and winter. Australian Journal of Zoology 54:15-21.

Leggett K. E. A. 2004. Coprophagy and unusual thermoregulatory behaviour in desert-dwelling elephants of north-western Namibia. Pachyderm 36:113-115.

Lewis R. E., Lewis J. H., Harrison D. L. 1965. On a collection of mammals from northern Saudi Arabia. Proceedings of the Zoological Society of London 144:61-74.

Lovegrove B. G., Raman J., Perrin M. R. 2001. Daily torpor in elephant shrews (Macroscelidea: Elephantulus spp.) in response to food deprivation. Journal of Comparative Physiology B: Biochemical, Systems, and Environmental Physiology 171:11-21.

Lowrey C., Longshore K. 2005. Long Term Conservation Strategy for Palmers Chipmunk (Tamias palmeri) within the Spring Mountains, Nevada. Henderson (Nevada): United States Geological Survey.

Lubbe A. 2013. Thermoregulatory plasticity in free-ranging vervet monkeys (Chlorocebus pygerythrus). [MSc. thesis]. Johannesburg (South Africa): University of the Witwatersrand.

Macfarlane W. V., Morris R. J. H., Howard B. 1963. Turnover and distribution of water in desert camels, sheep, cattle and kangaroos. Nature 197:270-271.

MacMillen R. E. 1965. Aestivation in the cactus mouse, Peromyscus eremicus. Comparative Biochemistry and Physiology 16:227-248.

MacMillen R. E., Lee A. K. 1967. Australian desert mice: independence of exogenous water. Science 158:383-385.

MacMillen R. E., Lee A. K. 1969. Water metabolism of Australian hopping mice. Comparative Biochemistry and Physiology 28:493-514.

Maloiy G. M. O. 1972. Comparative physiology of desert animals. Symposia of the Zoological Society of London 31:243-259.

Maloiy G. M. O. 1973. The water metabolism of a small East African antelope: the dik-dik. Proceedings of the Royal Society B: Biological Sciences 184:167-178.

Maloiy G. M. O., Rugangazi B. M., Clemens E. T. 1988. Physiology of the dik-dik antelope. Comparative Biochemistry and Physiology Part A: Physiology 91:1-8.

Maloney S. K., Moss G., Cartmell T., Mitchell D. 2005. Alteration in diel activity patterns as a thermoregulatory strategy in black wildebeest (Connochaetes gnou). Journal of Comparative Physiology A: Molecular and Integrative Physiology 191:1055-1064.

Marai I. F. M., Haeeb A. A. M. 2010. Buffalo's biological functions as affected by heat stress-a review. Livestock Science 127:89-109.

Mares M. A. 1977a. Water economy and salt balance in a South American desert rodent, Eligmodontia typus. Comparative Biochemistry and Physiology Part A: Physiology 56:325-332. 
Mares M. A. 1977b. Water independence in a South American non-desert rodent. Journal of Mammalogy 58:653-656.

Mares M. A. 1993. Desert rodents, seed consumption, and convergence: evolutionary shuffling of adaptations. BioScience 43:372-379.

Marsh A. C., Louw G., Berry H. H. 1978. Aspects of renal physiology, nutrition and therrnoregulation in the ground squirrel Xerus inauris. Madoqua 2:129-135.

Mbassa G. K. 1988. Mammalian renal modifications in dry environments. Veterinary Research Communications 12:1-18.

McCutchen H. E. 1981. Desert bighorn zoogeography and adaptation in relation to historic land use. Wildlife Society Bulletin 9:171-179.

McKean T., Walker B. 1974. Comparison of selected cardiopulmonary parameters between the pronghorn and the goat. Respiration Physiology 21:365370 .

Mendelssohn H., Yom-Tov Y. 1999. Mammalia of Israel. Jerusalem (Israel): Israel Academy of Sciences and Humanities.

Mengistu U., Dahlborn K., Olsson K. 2007. Effects of intermittent watering on water balance and feed intake in male Ethiopian Somali goats. Small Ruminant Research 67:45-54.

Merkt J. R., Taylor C. R. 1994. "Metabolic switch" for desert survival. Proceedings of the National Academy of Sciences of the United States of America 91:1231312316.

Misra A. K., Singh K. 2002. Effect of water deprivation on dry matter intake, nutrient utilization and metabolic water production in goats under semi-arid zone of India. Small Ruminant Research 46:159-165.

Mitchell D., Maloney S. K., Laburn H. P., Knight M. H., Kuhnen G., Jessen C. 1997. Activity, blood temperature and brain temperature of freeranging springbok. Journal of Comparative Physiology B: Biochemical, Systems, and Environmental Physiology 167:335-343.

Mitchell D., Maloney S. K., Jessen C., Laburn H. P., Kamerman P. R., Mitchell G., Fuller A. 2002. Adaptive heterothermy and selective brain cooling in arid-zone mammals. Comparative Biochemistry and Physiology B: Biochemistry and Molecular Biology 131:571-585.

Mitchell J., Mitchell G., Lust A. 2009. Thermoregulatory anatomy of pronghorn (Antilocapra americana). European Journal of Wildlife Research 55:23-31.

Morton S. R. 1978. An ecological study of Sminthopsis carasicaudata (Marsupialia: Dasyuridae). III. Reproduction and life history. Australian Wildlife Research 5:183-211.

Murray B. R., Dickman C. R., Watts C. H. S., Morton S. R. 1999. The dietary ecology of Australian rodents. Wildlife Research 26:857-858.
Nagy K. A. 1994. Seasonal water, energy and food use by free-living, arid-habitat mammals. Australian Journal of Zoology 42:55-63.

Nagy K. A., Knight M. H. 1994. Energy, water, and food use by springbok antelope (Antidorcas marsupialis) in the Kalahari desert. Journal of Mammalogy 75:860-872.

Naya D. E., Bacigalupe L. D., Bustamante D. M., Bozinovic F. 2005. Dynamic digestive responses to increased energy demands in the leaf-eared mouse (Phyllotis darwini). Journal of Comparative Physiology B: Biochemical, Systems, and Environmental Physiology 175:31-36.

Nel J. A. J. 1984. Behavioural ecology of canids in the south-western Kalahari. Koedoe Supplement (1984):229-235.

Noll-Banholzer U. 1979. Body temperature, oxygen consumption, evaporative water loss and heart rate in the fennec. Comparative Biochemistry and Physiology Part A: Physiology 62:585-592.

Nowack J., Dausmann K. H., Mzilikazi N. 2013. Nonshivering thermogenesis in the African lesser bushbaby, Galago moholi. Journal of Experimental Biology 216:3811-3817.

Osborn S. D. 1991. Adaptive heterothermy in desert mammals. [PhD thesis]. Tucson (Arizona): University of Arizona.

Ostrowski S., Williams J. B. 2006. Heterothermy of free-living Arabian sand gazelles (Gazella subgutturosa marica) in a desert environment. Journal of Experimental Biology 209:1421-1429.

Ostrowski S., Williams J. B., Bedin E., Ismail K. 2002. Water influx and food consumption of free-living oryxes (Oryx leucoryx) in the Arabian desert in summer. Journal of Mammalogy 83:665-673.

Ostrowski S., Williams J. B., Ismael K. 2003. Heterothermy and the water economy of free-living Arabian oryx (Oryx leucoryx). Journal of Experimental Biology 206:1471-1478.

Ostrowski S., Williams J. B., Mésochina P., Sauerwein H. 2006. Physiological acclimation of a desert antelope, Arabian oryx (Oryx leucoryx), to long-term food and water restriction. Journal of Comparative Physiology B: Biochemical, Systems, and Environmental Physiology 176:191-201.

Ouajd S., Kamel B. 2009. Physiological particularities of dromedary (Camelus dromedarius) and experimental implications. Scandinavian Journal of Laboratory Animal Science 36:19-29.

Oyewale J., Dzenda T., Yaqub L., Akanbi D., Ayo J., Owoyele O., Minka N., Dare T. 2011. Alterations in the osmotic fragility of camel and donkey erythrocytes caused by temperature, $\mathrm{pH}$ and blood storage. Veterinarski Arhiv 81:459-470.

Peinke D. M., Brown C. R. 1999. Osmoregulation and water balance in the springhare (Pedetes capensis). Journal of Comparative Physiology B: Biochemical, Systems, and Environmental Phsyiology 169:1-10. 
Perrin M. R., Downs C. T. 1994. Comparative aspects of the thermal biology of the Cape spiny mouse, Acomys subspinosus, and the common spiny mouse, A. spinosissimus. Israel Journal of Zoology 40:151-160.

Portas T. J., Lynch M. J., Vogelnest L. 2003. Comparison of etorphine-detomidine and medetomidine-ketamine anesthesia in captive addax (Addax nasomaculatus). Journal of Zoo and Wildlife Medicine 34:269-273.

Purohit K. G. 1971. Absolute duration of survival of tammar wallaby (Macropus eugenii, Marsupialia) on sea water and dry food. Comparative Biochemistry and Physiology Part A: Physiology 39:473-481.

Rainho A. 2007. Summer foraging habitats of bats in a Mediterranean region of the Iberian Peninsula. Acta Chiropterologica 9:171-181.

Randall J. A. 1997. Species-specific footdrumming in kangaroo rats: Dipodomys ingens, D. deserti, D. spectabilis. Animal Behaviour 54:1167-1175.

Randall J. A., Rogovin K., Parker P. G., Eimes J. A. 2005. Flexible social structure of a desert rodent, Rhombomys opimus: philopatry, kinship, and ecological constraints. Behavioral Ecology 16:961-973.

Rathbun G. B., Rathbun C. D. 2005. Noki or dassierat (Petromus typicus) feeding ecology and petrophily. Belgian Journal of Zoology 135 (Supplement): 69-75.

Rautenstrauch K. R., Krausman P. R. 1989. Influence of water availability and rainfall on movements of desert mule deer. Journal of Mammalogy 70:197-201.

Reese J. B., Haines H. 1978. Effects of dehydration on metabolic rate and fluid distribution in the jackrabbit, Lepus californicus. Physiological Zoology 51: 155-165.

Rickart E. A. 1986. Serum thyroxine and seasonal fattening of free-living piute ground squirrels, Spermophilus mollis (Rodentia: Sciuridae). Comparative Biochemistry and Physiology Part A: Physiology 85: 199-202.

Ron U., Haim A. 2001. How dehydration affects the thermoregulatory and osmoregulatory abilities of the golden spiny mouse Acomys russatus. Israel Journal of Zoology 47:15-20.

Rubal A., Choshniak I., Haim A. 1992. Daily rhythms of metabolic rate and body temperature of two murids from extremely different habitats. Chronobiology International 9:341-349.

Rübsamen K., Kettembeil S. 1980. Effect of water restriction on oxygen uptake, evaporative water loss and body temperature of the rock hyrax. Journal of Comparative Physiology B: Biochemical, Systems, and Environmental Physiology 138:315-320.

Rugangazi B. M., Maloiy G. M. O. 1988. Renal excretion of urea in a small east African antelope, the dik-dik (Rhynchotragus kirkii). Comparative Biochemistry and Physiology Part A: Physiology 91:437-444.
Saadi L., Lebaili N. 2012. Effect of a water-rich diet on adrenal zone glomerulosa in Gerbillus tarabuli. Comptes Rendus Biologies 335:96-102.

Salsamendi E., Arostegui I., Aihartza J., Almenar D., Goiti U., Garin I. 2012. Foraging ecology in Mehely's horseshoe bats: influence of habitat structure and water availability. Acta Chiropterologica 14:121-132.

Sassi P. L., Borghi C. E., Bozinovic F. 2007. Spatial and seasonal plasticity in digestive morphology of cavies (Microcavia australis) inhabiting habitats with different plant qualities. Journal of Mammalogy 88:165-172.

Sassi P. L., Caviedes-Vidal E., Anton R., Bozinovic F. 2010. Plasticity in food assimilation, retention time and coprophagy allow herbivorous cavies (Microcavia australis) to cope with low food quality in the Monte desert. Comparative Biochemistry and Physiology Part A: Molecular and Integrative Physiology 155:378-382.

Scantlebury M., Bennett N. C., Speakman J. R., Pillay N., Schradin C. 2006. Huddling in groups leads to daily energy savings in free-living African fourstriped grass mice, Rhabdomys pumilio. Functional Ecology 20:166-173.

Schmid J. 2001. Daily torpor in free-ranging gray mouse lemurs (Microcebus murinus) in Madagascar. International Journal of Primatology 22:1021-1031.

Schmid J., Speakman J. R. 2009. Torpor and energetic consequences in free-ranging grey mouse lemurs (Microcebus murinus): a comparison of dry and wet forests. Naturwissenschaften 96:609-620.

Schmidt-Nielsen B., Schmidt-Nielsen K. 1951. A complete account of the water metabolism in kangaroo rats and an experimental verification. Journal of Cellular and Comparative Physiology 38:165-181.

Schmidt-Nielsen B., Schmidt-Nielsen K., Houpt T. R., Jarnum S. A. 1956. Water balance of the camel. American Journal of Physiology 185:185-194.

Schmidt-Nielsen K., Schmidt-Nielsen B. 1952. Water metabolism of desert mammals. Physiological Reviews 32:135-166.

Schmidt-Nielsen K., Schmidt-Nielsen B., Brokaw A. 1948. Urea excretion in desert rodents exposed to high protein diets. Journal of Cellular and Comparative Physiology 32:361-379.

Schmidt-Nielsen K., Crawford E. C. Jr., Newsome A. E., Rawson K. S., Hammel H. T. 1967. Metabolic rate of camels: effect of body temperature and dehydration. American Journal of Physiology 212:341-346.

Schmidt-Nielsen K., Hainsworth F. R., Murrish D. E. 1970. Counter-current heat exchange in the respiratory passages: effect on water and heat balance. Respiration Physiology 9:263-276.

Schmidt-Nielsen K., Schroter R. C., Shkolnik A. 1981a. Desaturation of exhaled air in camels. Proceedings of the Royal Society B: Biological Sciences 211:305-319. 
Schmidt-Nielsen K., Crawford E. C., Hammel H. T. 1981b. Respiratory water loss in camels. Proceedings of the Royal Society B: Biological Sciences 211:291-303.

Schoepf I., Schradin C. 2014. Arginine vasopressin plasma levels change seasonally in African striped mice but do not differ between alternative reproductive tactics. General and Comparative Endocrinology 204:43-48.

Schradin C. 2005. Nest-site competition in two diurnal rodents from the succulent karoo of South Africa. Journal of Mammalogy 86:757-762.

Schradin C. 2006. Whole-day follows of striped mice (Rhabdomys pumilio), a diurnal murid rodent. Journal of Ethology 24:37-43.

Schradin C., Pillay N. 2005a. Demography of the striped mouse (Rhabdomys pumilio) in the succulent karoo. Mammalian Biology 70:84-92.

Schradin C., Pillay N. 2005b. Intraspecific variation in the spatial and social organization of the African striped mouse. Journal of Mammalogy 86: 99-107.

Schradin C., Pillay N. 2006. Female striped mice (Rhabdomys pumilio) change their home ranges in response to seasonal variation in food availability. Behavioral Ecology 17:452-458.

Schradin C., Krackow S., Schubert M., Keller C., Schradin B., Pillay N. 2007. Regulation of activity in desert-living striped mice: the importance of basking. Ethology 113:606-614.

Schradin C., Schmohl G., Rödel H. G., Schoepf I., Treffler S. M., Brenner J., Bleeker M., Schubert M., König B., Pillay N. 2010. Female home range size is regulated by resource distribution and intraspecific competition: a long-term field study. Animal Behaviour 79:195-203.

Schradin C., Lindholm A. K., Johannesen J., Schoepf I., Yuen C.-H., König B., Pillay N. 2012. Social flexibility and social evolution in mammals: a case study of the African striped mouse (Rhabdomys pumilio). Molecular Ecology 21:541-553.

Schradin C., Raynaud J., Arrivé M., Blanc S. 2014. Leptin levels in free ranging striped mice (Rhabdomys pumilio) increase when food decreases: the ecological leptin hypothesis. General and Comparative Endocrinology 206:139-145.

Schreiber R. K. 1979. Coefficients of digestibility and caloric diet of rodents in the northern Great Basin desert. Journal of Mammalogy 60:416-420.

Schreier A. L., Swedell L. 2012. Ecology and sociality in a multilevel society: ecological determinants of spatial cohesion in Hamadryas baboons. American Journal of Physical Anthropology 148:580-588.

Schubert M., Pillay N., Ribble D. O., Schradin C. 2009. The round-eared sengi and the evolution of social monogamy: factors that constrain males to live with a single female. Ethology 115:972-985.
Schulz E., Fraas S., Kaier T. M., Cunningham P. L., Ismail K., Wronski T. 2013. Food preferences and tooth wear in the sand gazelle (Gazella marica). Mammalian Biology 78:55-62.

Schumann D. M., Cooper H. M., Hofmeyr M. D., Bennett N. C. 2005. Circadian rhythm of locomotor activity in the four-striped field mouse, Rhabdomys pumilio: a diurnal African rodent. Physiology and Behavior 85:231-239.

Selim H. M., Imai S., El Sheik A. K., Attia H., Okamoto E., Miyagawa E., Maede Y. 1999. Rumen ciliate protozoal fauna of native sheep, friesian cattle and dromedary camel in Libya. Journal of Veterinary Medical Science 61:303-305.

Shanas U., Haim A. 2004. Diet salinity and vasopressin as reproduction modulators in the desert-dwelling golden spiny mouse (Acomys russatus). Physiology and Behavior 81:645-650.

Shaw W. T. 1934. The ability of the giant kangaroo rat as a harvester and storer of seeds. Journal of Mammalogy 15:275-286.

Shkolnik A., Borut A. 1969. Temperature and water relations in two species of spiny mice (Acomys). Journal of Mammalogy 50:245-255.

Shoemaker V. H., Nagy K. A., Costa W. R. 1976. Energy utilization and temperature regulation by jackrabbits (Lepus californicus) in the Mojave Desert. Physiological Zoology 49:364-375.

Siebert B. D., Macfarlane W. V. 1971. Water turnover and renal function of dromedaries in the desert. Physiological Zoology 44:225-240.

Siebert B. D., Macfarlane W. V. 1975. Dehydration in desert cattle and camels. Physiological Zoology 48:36-48.

Silanikove N., Tagari H., Shkolnik A. 1980. Gross energy digestion and urea recycling in the desert black Bedouin goat. Comparative Biochemistry and Physiology Part A: Physiology 67:215-218.

Sneddon J. C., Boomker E., Howard C. V. 2006. Mucosal surface area and fermentation activity in the hind gut of hydrated and chronically dehydrated working donkeys. Journal of Animal Science 84:119-124.

Soholt L. F. 1974. Environmental conditions in an artificial burrow occupied by Merriam's kangaroo rat, $\mathrm{Di}$ podomys merriami. Journal of Mammalogy 55:859-864.

Song X., Geiser F. 1997. Daily torpor and energy expenditure in Sminthopsis macroura: interactions between food and water availability and temperature. Physiological Zoology 70:331-337.

Spalton J. A. 1999. The food supply of the Arabian oryx (Oryx leucoryx) in the desert of Oman. Journal of Zoology 248:433-441.

Stewart D. R. M. 1963. The Arabian oryx (Oryx leucoryx Pallas). African Journal of Ecology 1:103-117.

Taylor C. R. 1969. Metabolism, respiratory changes, and water balance of an antelope, the eland. American Journal of Physiology 217:317-320. 
Taylor C. R. 1970a. Dehydration and heat: effects on temperature regulation of East African ungulates. American Journal of Physiology 219:1136-1139.

Taylor C. R. 1970b. Strategies of temperature regulation: effect on evaporation in East African ungulates. American Journal of Physiology 219:1131-1135.

Timm R. M., Kermott L. H. 1982. Subcutaneous and cutaneous melanins in Rhabdomys: complementary ultraviolet radiation shields. Journal of Mammalogy 63:16-22.

Tirado C., Cortés A., Bozinovic F. 2008. Water balance in two South American Phyllotis desert rodents, $P$. xanthopygus rupestris and $P$. darwini darwini. Journal of Arid Environments 72:664-670.

Turner J. C. 1970. Water consumption of desert bighorn sheep. Desert Bighorn Council Transactions 14:189-197.

Turner J. C. 1979. Osmotic fragility of desert bighorn sheep red blood cells. Comparative Biochemistry and Physiology Part A: Physiology 64:167-175.

Veloso C., Bozinovic F. 1993. Dietary and digestive constraints on basal energy metabolism in a small herbivorous rodent. Ecology 74:2003-2010.

Vermeulen H. C., Nel J. A. J. 1988. The bush Karoo rat Otomys unisulcatus on the Cape West coast. South African Journal of Zoology 23:103-111.

Walker F. M., Taylor A. C., Sunnucks P. 2007. Does soil type drive social organization in southern hairynosed wombats? Molecular Ecology 16:199-208.

Walsberg G. E. 1988. Consequences of skin color and fur properties for solar heat gain and ultraviolet irradiance in two mammals. Journal of Comparative Physiology B: Biochemical, Systems, and Environmental Physiology 158:213-221.

Warneke L., Turner J. M., Geiser F. 2008. Torpor and basking in a small arid zone marsupial. Naturwissenschaften 95:73-78.

Waterman J. M., Herron M. D. 2004. Xerus princeps. Mammalian Species 751:1-3.

Williams J. B., Ostrowski S., Bedin E., Ismail K. 2001. Seasonal variation in energy expenditure, water flux and food consumption of Arabian oryx Oryx leucoryx. Journal of Experimental Biology 204:2301-2311.
Williams J. B., Lenain D., Ostrowski S., Tielman B. I., Seddon P. J. 2002. Energy expenditure and water flux of Rüppell's foxes in Saudi Arabia. Physiological and Biochemical Zoology 75:479-488.

Wilson R. T. 1989. Ecophysiology of the Camelidae and Desert Ruminants. Berlin (Germany): Springer-Verlag.

Winkelmann J. R., Getz L. L. 1962. Water balance in the Mongolian gerbil. Journal of Mammalogy 43:150-154.

Withers P. C., Cooper C. E. 2009. Thermal, metabolic, and hygric physiology of the little red kaluta, Dasykaluta rosamondae (Dasyuromorphia: Dasyuridae). Journal of Mammalogy 90:752-760.

Withers P. C., Lee A. K., Martin R. W. 1979. Metabolism, respiration and evaporative water loss in the Australian hopping-mouse Notomys alexis (Rodentia: Muridae). Australian Journal of Zoology 27:195-204.

Wittenberg C., Choshniak I., Shkolnik A., Thurau K., Rosenfeld J. 1986. Effect of dehydration and rapid rehydration on renal function and on plasma renin and aldosterone levels in the black Bedouin goat. Pflügers Archiv 406:405-408.

Woodroffe R. 2011. Ranging behaviour of African wild dog packs in a human-dominated landscape. Journal of Zoology 283:88-97.

Yagil R. 1985. The desert camel: comparative physiological adaptation. Comparative Animal Nutrition 5:1-164.

Young R. A. 1976. Fat, energy and mammalian survival. American Zoologist 16:699-710.

Yousef M. K., Johnson H. D. 1975. Thyroid activity in desert rodents: a mechanism for lowered metabolic rate. American Journal of Physiology 229:427-431.

Yousef M. K., Dill D. B., Mayes M. G. 1970. Shifts in body fluids during dehydration in the burro, Equus asinus. Journal of Applied Physiology 29:345-349.

Zervanos S. M., Hadley N. F. 1973. Adaptational biology and energy relationships of the collared peccary ( $\mathrm{Ta}$ yassu tajacu). Ecology 54:759-774.

Zhang Z.-Q., Wang D.-H. 2007. Seasonal changes in thermogenesis and body mass in wild Mongolian gerbils (Meriones unguiculatus). Comparative Biochemistry and Physiology Part A: Molecular and Integrative Physiology 148:346-353. 